\title{
Did high Neo-Tethys subduction rates contribute to early Cenozoic warming?
}

\author{
G. Hoareau $^{1,2}$, B. Bomou ${ }^{1,3,4}$, D. J. J. van Hinsbergen ${ }^{5}$, N. Carry ${ }^{1}$, D. Marquer ${ }^{1}$, Y. Donnadieu ${ }^{4}$, G. Le Hir ${ }^{3}$, \\ B. Vrielynck ${ }^{6}$, and A.-V. Walter-Simonnet ${ }^{1}$ \\ ${ }^{1}$ UMR 6249 Chrono-environnement (CNRS-Université de Franche-Comté), 25030 Besançon CEDEX, France \\ ${ }^{2}$ UMR CNRS TOTAL 5150 Laboratoire des Fluides Complexes et leurs Réservoirs, Université de Pau et des Pays de l'Adour, \\ I.P.R.A., Avenue de l'Université BP 1155, 64013 PAU CEDEX, France \\ ${ }^{3}$ Institut de Physique du Globe de Paris, 4 place Jussieu, 75005 Paris, France \\ ${ }^{4}$ LSCE/UVSQ/IPSL CEA Saclay, Orme des Merisiers, 91191 Gif-sur-Yvette, France \\ ${ }^{5}$ Department of Earth Sciences, Utrecht University, Budapestlaan 4, 3584 CD Utrecht, the Netherlands \\ ${ }^{6}$ UMR 7193 - ISTEP (CNRS-UPMC), 4 place Jussieu, 75252 Paris CEDEX 05, France
}

Correspondence to: G. Hoareau (guilhem.hoareau@univ-pau.fr)

Received: 28 May 2015 - Published in Clim. Past Discuss.: 8 July 2015

Revised: 4 November 2015 - Accepted: 25 November 2015 - Published: 18 December 2015

\begin{abstract}
The 58-51 Ma interval was characterized by a long-term increase of global temperatures $\left(+4\right.$ to $\left.+6{ }^{\circ} \mathrm{C}\right)$ up to the Early Eocene Climate Optimum (EECO, 52.9$50.7 \mathrm{Ma}$ ), the warmest interval of the Cenozoic. It was recently suggested that sustained high atmospheric $p \mathrm{CO}_{2}$, controlling warm early Cenozoic climate, may have been released during Neo-Tethys closure through the subduction of large amounts of pelagic carbonates and their recycling as $\mathrm{CO}_{2}$ at arc volcanoes. To analyze the impact of NeoTethys closure on early Cenozoic warming, we have modeled the volume of subducted sediments and the amount of $\mathrm{CO}_{2}$ emitted along the northern Tethys margin. The impact of calculated $\mathrm{CO}_{2}$ fluxes on global temperature during the early Cenozoic have then been tested using a climate carbon cycle model (GEOCLIM). We show that $\mathrm{CO}_{2}$ production may have reached up to $1.55 \times 10^{18} \mathrm{~mol} \mathrm{Ma}^{-1}$ specifically during the EECO, 4 to $37 \%$ higher that the modern global volcanic $\mathrm{CO}_{2}$ output, owing to a dramatic IndiaAsia plate convergence increase. The subduction of thick Greater Indian continental margin carbonate sediments at $\sim 55-50 \mathrm{Ma}$ may also have led to additional $\mathrm{CO}_{2}$ production of $3.35 \times 10^{18} \mathrm{~mol} \mathrm{Ma}^{-1}$ during the EECO, making a total of $85 \%$ of the global volcanic $\mathrm{CO}_{2}$ outgassed. However, climate modeling demonstrates that timing of maximum $\mathrm{CO}_{2}$ release only partially fits with the EECO, and that corresponding maximum $p \mathrm{CO}_{2}$ values $(750 \mathrm{ppm})$ and sur-
\end{abstract}

face warming $\left(+2{ }^{\circ} \mathrm{C}\right)$ do not reach values inferred from geochemical proxies, a result consistent with conclusions arising from modeling based on other published $\mathrm{CO}_{2}$ fluxes. These results demonstrate that $\mathrm{CO}_{2}$ derived from decarbonation of Neo-Tethyan lithosphere may have possibly contributed to, but certainly cannot account alone for early Cenozoic warming. Other commonly cited sources of excess $\mathrm{CO}_{2}$ such as enhanced igneous province volcanism also appear to be up to 1 order of magnitude below fluxes required by the model to fit with proxy data of $p \mathrm{CO}_{2}$ and temperature at that time. An alternate explanation may be that $\mathrm{CO}_{2}$ consumption, a key parameter of the long-term atmospheric $p \mathrm{CO}_{2}$ balance, may have been lower than suggested by modeling. These results call for a better calibration of early Cenozoic weathering rates.

\section{Introduction}

Based on paleotemperature proxies, a trend of decreasing global temperatures throughout the Late Mesozoic and Cenozoic has long been identified (e.g, Shackelton and Kennett, 1975; Zachos et al., 2001, 2008; Cramer et al., 2009; Friedrich et al., 2012). Climatic modeling suggests that this cooling mainly results from decreasing seafloor spreading and subduction rates, as well as increasing $\mathrm{CO}_{2}$ removal 
through silicate weathering (Park and Royer, 2011; Godderis et al., 2014; van der Meer et al., 2014). During the Cenozoic, $\mathrm{CO}_{2}$ consumption was mainly governed by the erosion of the Tethyan orogenic belt, and by continental drift, responsible for the arrival of highly weatherable basaltic provinces in the equatorial belt (Raymo and Ruddiman, 1992; Kent and Muttoni, 2013; Lefebvre et al., 2013). However, global cooling was interrupted by a long-term increase of global temperatures $\left(+4\right.$ to $\left.+6{ }^{\circ} \mathrm{C}\right)$ and $p \mathrm{CO}_{2}(\sim 450$ to $\sim 1000 \mathrm{ppm})$ from 58 to $50.7 \mathrm{Ma}$, crowned by the Early Eocene Climate Optimum (EECO, 52.9-50.7 Ma), the warmest interval of the Cenozoic (Zachos et al., 2001; Beerling and Royer, 2011). Because conventional carbon cycle models compute important weathering rates at that time, they fail to reproduce this rise in temperature and atmospheric $\mathrm{CO}_{2}$ without the addition of excess $\mathrm{CO}_{2}$ compared to background $\mathrm{CO}_{2}$ volcanic degassing rates $\left(4-10 \times 10^{18} \mathrm{molCO}_{2} \mathrm{Ma}^{-1}\right.$ at present; Berner, 2004) (Lefebvre et al., 2013; Van der Meer et al., 2014). Carbonates also indicate that from $\sim 58.0$ to $52.5 \mathrm{Ma}$ this warming was characterized by a 2 per mil negative shift in marine and terrestrial $\delta^{13} \mathrm{C}$, referred to as the Late Paleocene-Early Eocene (LPEE) by Komar et al. (2013). This drop in $\delta^{13} \mathrm{C}$ suggests an additional source of depleted $\mathrm{CO}_{2}$ (i.e enriched in ${ }^{12} \mathrm{C}$ ) or/and decreased net organic carbon burial (Hilting et al, 2008; Komar et al. 2013). In contrast, despite warm temperature, the EECO was associated with a rise in $\delta^{13} \mathrm{C}$ (Cramer et al., 2009), indicative of the addition of heavy $\mathrm{CO}_{2}$ or/and alternatively by increased net organic carbon burial (e.g., Komar et al., 2013). Various origins of excess $\mathrm{CO}_{2}$ have been proposed for both periods of the early Cenozoic. Most invoke the activity of large igneous provinces such as the North Atlantic Igneous Province (NAIP), since a mantellic source of $\mathrm{CO}_{2}\left(\delta^{13} \mathrm{CO}_{2}\right.$ ranging from -3 to $-10 \%$ ) may be compatible with carbon isotope proxies for most of the period of warming (see Reagan et al. 2013 and references therein). Alternatively, Beck et al. (1995), Hilting et al. (2008) and Komar et al. (2013) proposed that large amounts of low- $\delta^{13} \mathrm{C}$ organic carbon were being stored in carbon capacitors separate from the oceanatmosphere-biosphere (e.g., peat, gas hydrates, permafrost) during the Paleocene. They were then massively released during the LPEE warming and progressively vanished during the EECO (Komar et al., 2013). Finally, among several other hypotheses, it was suggested that Neo-Tethys closure may have strongly controlled Cretaceous and early Cenozoic climates, up to the EECO, through the subduction of tropical pelagic carbonates $\left(\delta^{13} \mathrm{C} \sim 0 \%\right.$ ) under the Asian plate and their recycling as $\mathrm{CO}_{2}$ at arc volcanoes (Edmond and Huh, 2003; Kent and Muttoni, 2008; Johnston et al., 2011). These authors argued that the tropical latitudes of the northern Neo-Tethys could have favored deposition of carbonaterich pelagic sediments on the Tethyan seafloor. In detail, Kent and Muttoni (2008) suggested that the Indian plate dominated this "carbonate subduction factory", with a major decrease in $\mathrm{CO}_{2}$ production as India and Asia collided some
$50 \mathrm{Ma}$ ago. However, the same authors recently concluded for low $\mathrm{CO}_{2}$ outgassing at the Tethyan arc, mainly as a result of low decarbonation during subduction (Kent and Muttoni, 2013). For Kent and Muttoni (2013), high $\mathrm{CO}_{2}$ could be explained by less efficient weathering close to the EECO, rather than by additional $\mathrm{CO}_{2}$ production.

In this contribution, we aim to test whether Neo-Tethyan closure, which was obviously associated with widespread arc volcanism, may or may not have had an impact on global warming during the LPEE and the EECO, keeping in mind that this hypothesis hardly conforms to available carbon isotope records during the LPEE. To this end, we first use a simple model that calculates the volume of sediments subducted along with Neo-Tethyan oceanic and Greater Indian margin lithospheres, and computes a range of $\mathrm{CO}_{2}$ fluxes emitted at active arc volcanoes along the northern Neo-Tethys margin. A coupled climate-carbon cycle model (GEOCLIM) is then used to quantify the impact of $\mathrm{CO}_{2}$ fluxes obtained from our model and that of Kent and Muttoni (2013), on Paleocene/Eocene $p \mathrm{CO}_{2}$ and atmospheric temperature. Finally, in light of our results, we discuss the relevance of alternate hypotheses commonly cited to explain the LPEE and the EECO.

\section{Neo-Tethyan history and related arc volcanism}

The Neo-Tethys ocean opened westward during the Permian to Triassic, separating several micro-continents (e.g., Pontides, Central Iran, Central Afghanistan, Tibet, and Western Myanmar) from Gondwana in the south (Kazmin, 1991; Dercourt et al., 1993; Ricou, 1994; Stampfli and Borel 2002; Muttoni et al., 2009). These reached the southern Eurasian margin in Late Triassic and younger times, followed by inception of subduction of Neo-Tethyan oceanic lithosphere. In the western Neo-Tethys, convergence of Africa to Eurasia began in the Aptian (Kazmin, 1991; Dercourt et al., 1993; Ricou, 1994; Rosenbaum and Lister, 2002; Stampfli and Borel, 2002; van Hinsbergen et al., 2005) (Fig. 1). NeoTethys subduction below the Iran margin started at least in Jurassic time and continued until Arabia-Eurasia collision in latest Eocene-Early Oligocene time (Agard et al., 2011; Mouthereau, 2011; McQuarrie and van Hinsbergen, 2013). Subduction below Tibet in the Early Cretaceous occurred simultaneously with Indian separation from eastern Antarctica and Australia $\sim 130 \mathrm{Ma}$ ago (Guillot et al., 2008; van Hinsbergen et al., 2011a). Collision between the northernmost continental crust of the Indian plate and Eurasia is commonly stated to have started between $\sim 60$ and $\sim 50 \mathrm{Ma}$ (e.g., Dupont-Nivet et al., 2010; Najman et al., 2010; Orme et al., 2014; Hu et al., 2015) (Fig. 1). At about the same time ( 56-47 Ma), subducted Indian northern margin rocks were affected by high-pressure and ultra-high pressure metamorphism (up to $\sim 100 \mathrm{~km}$ depth) (Guillot et al., 2008). In the easternmost Neo-Tethys (Indonesia), Whittaker et al. (2007) 
suggested that active subduction below Eurasia was active throughout the Upper Cretaceous and the Cenozoic, although Hall (2012) proposed that Sundaland was mostly surrounded by inactive, or transform margins from 90 to $45 \mathrm{Ma}$. Finally, there is also documentation for multiple intra-oceanic subduction events leading to widespread ophiolite obduction, ending around $70 \mathrm{Ma}$ along NE Arabia, and around 55$50 \mathrm{Ma}$ in SE Oman, Pakistan (Gnos et al., 1997; Marquer et al., 1998; Gaina et al., 2015), and the Tibetan Himalaya (Hébert et al., 2012; Garzanti and Hu, 2014; Huang et al., 2015a) (Fig. 1).

Evidence of latest Cretaceous and early Cenozoic subduction-related magmatic activity is widespread along, and restricted to the Eurasian margin. For example, in the Zagros mountains and Turkey (Pontides), widespread arc magmatism occurred during the Mesozoic and the Cenozoic (Sengör et al., 1988; Okay and Şahintürk, 1997; Barrier and Vrielynck, 2008; Agard et al., 2011; Eyuboglu et al., 2011). In southern Tibet, a long-lasting volcanic 'Gangdese' arc was active from Early Cretaceous to Eocene time (Ji et al., 2009), with a short-lived ignimbrite flare-up stage around $50 \mathrm{Ma}$ coinciding with Tibetan Himalaya-Lhasa continental collision (Ji et al., 2009), followed by return of the arc to a background state until the Late Eocene (Sanchez et al., 2013). In Sundaland, Paleocene-Eocene magmatism was likely active since at least $\sim 63 \mathrm{Ma}$ (e.g., McCourt et al., 1996; Bellon et al., 2004).

\section{Volcanic $\mathrm{CO}_{2}$ release during the LPEE and the EECO by the Carbonate Subduction Factory Model (CSFM)}

CSFM is designed to calculate the amount of $\mathrm{CO}_{2}$ produced during Neo-Tethys closure. It quantifies the Neo-Tethys volcanic arc gas output as a function of subduction flux of oceanic crust, pelagic sediments, and also of Indian margin sediments at the onset of Indian continental lithosphere subduction. Required input parameters are subduction rate, trench length, the thickness, density, carbonate and organic carbon content of sediments and oceanic crust, the decarbonation efficiency of subducted material, and the time-lag to gas emission at the surface.

\subsection{Subduction rates and trench length estimates}

Subduction rates of African, Arabian and Indian plates below Eurasia were calculated from plate motion reconstructions made with GPlates (http://www.gplates.org/) (Boyden et al, 2011) using time steps of $0.5 \mathrm{Ma}$, between 65 and $35 \mathrm{Ma}$. Given the controversy regarding the presence or not of continuous subduction in easternmost Neo-Tethys from the Late Cenozoic to the Eocene (Sundaland) (e.g., Whittaker et al., 2007; Hall, 2012), we did not consider AustraliaEurasia convergence and assess the potential role of NeoTethys subduction based on the central and western Neo-
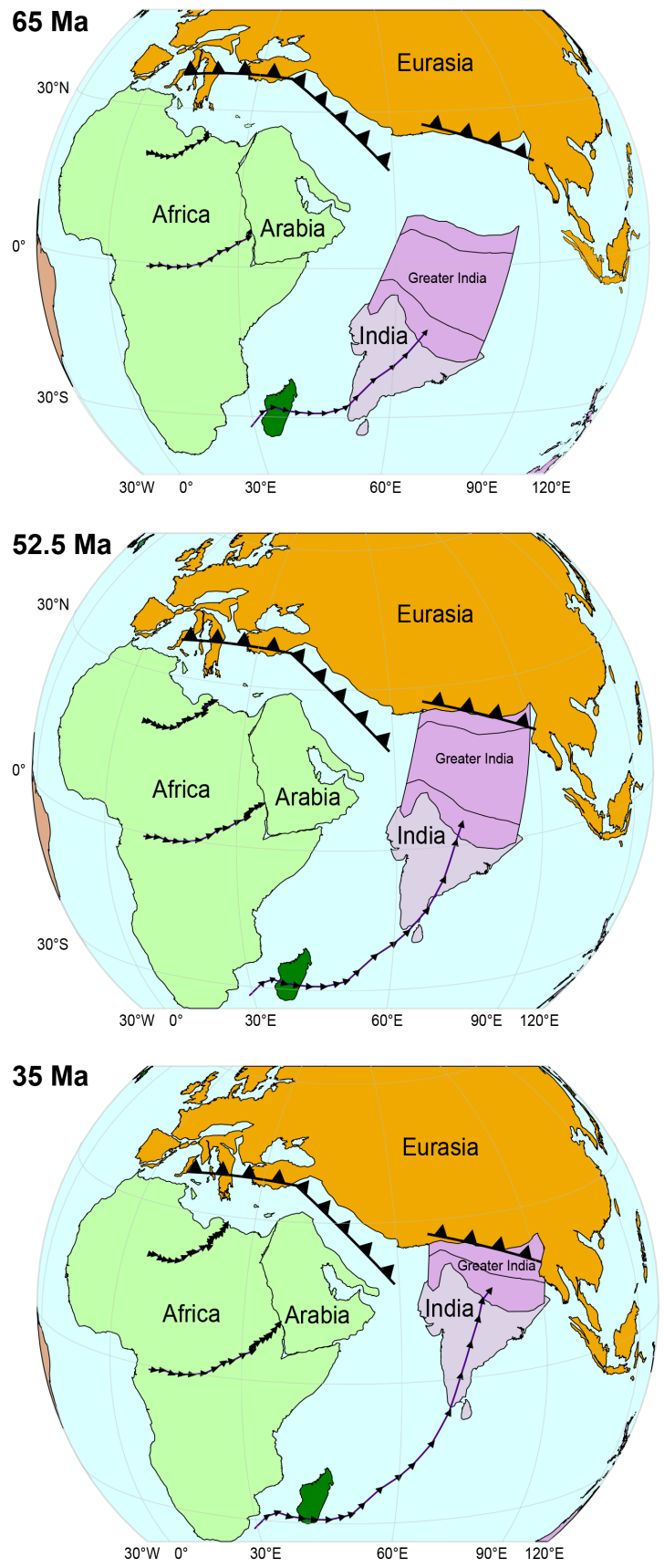

Figure 1. Simplified paleogeographic maps showing the positions of Africa, Arabia, India and Eurasia at $65,52.5$ and $35 \mathrm{Ma}$ (3D Globe projection; rotation poles of Müller et al. (2008), fixed Eurasian frame). The bearing and/or length of subduction trenches used in the model are represented as black lines. Flow lines (65$35 \mathrm{Ma}$ ) of three points representative of the central syntaxis of each plate are also reported (see text for present locations). Extension of Greater India during the Upper Cretaceous is based on the Greater India Basin hypothesis of Van Hinsbergen et al. (2012). 
Tethys alone. We used the reconstructed position of three points located on the western, central and eastern syntaxis of each plate, similar to Rosenbaum and Lister (2002), Alvarez (2010) and van Hinsbergen et al. (2011a). Their present locations in lat./long. decimal coordinates are 37/15, 32/24, 24/32 (Africa), 24.1/32.9, 15.3/38.9, 23.6/58.6 (Arabia) and 30.5/72, 30.5/82, 23.5/92 (India). Euler rotation parameters were taken from plate circuit A of van Hinsbergen et al. (2011a). Because Cretaceous-Cenozoic intra-Eurasian shortening north of the African-Arabian plate is limited to perhaps $200 \mathrm{~km}$ and focused in the late Cenozoic (e.g., Mouthereau, 2011; McQuarrie and van Hinsbergen, 2013), we considered Africa/Arabia-Eurasia convergence rates as subduction rates. For India, the subduction rate was calculated subtracting intra-Asian shortening rates expressed as Euler rotation parameters by van Hinsbergen et al. (2011b) from India-Asia convergence rates. Given the uncertainties concerning the rate of subduction below widespread ophiolites, and the locations of these subduction zones, we chose to simplify our scenario by assigning all subduction to the zones indicated in Fig. 1. In addition, we assume that there was no active spreading within the Neo-Tethys since $65 \mathrm{Ma}$. For each plate, subduction rates at each time step were corrected for convergence obliquity related to the orientation of the subduction trench (Annex 1). Trench lengths were set to $2500 \mathrm{~km}$ for Africa, $2900 \mathrm{~km}$ for Arabia (from the Levant fault to the Makran) and $2600 \mathrm{~km}$ for India (from the Makran to the Indo-Burma range), making a total length of $8000 \mathrm{~km}$ (similar to Johnston et al., 2011) (Fig. 1). Three ages, 55, 52.5 and $50 \mathrm{Ma}$, were tested for the onset of Greater Indian thinned continental lithosphere subduction beneath Eurasia, corresponding to a shift from pelagic to margin sediments on the Indian plate. Scenarios without India-Asia continental subduction were also run, to assess the maximum potential effects of younger collision.

\subsection{Geometric and lithological parameters}

\subsubsection{Oceanic crust and pelagic sediments}

In the model, all oceanic lithosphere has the same crust and sediment thickness. For the oceanic crust a constant thickness of $7 \mathrm{~km}$ and a density of $3 \mathrm{t} \mathrm{m}^{-3}$ were retained. Because subducted Neo-Tethyan crust was older than $40 \mathrm{Ma}$ during the Paleocene/Eocene, it was ascribed a carbonate content of $0.2 \mathrm{wt} \%$ (Alt and Teagle, 1999). For pelagic sediments, we adopted a carbonate content of typical deep-sea carbonate oozes (90 wt\%) (Kroenke et al., 1991), an organic carbon content of $1 \mathrm{wt} \%$, a thickness of $200 \mathrm{~m}$, and a density of $1.9 \mathrm{t} \mathrm{m}^{-3}$, similar to uncompacted deep-sea deposits (Sykes, 1996). These values are close to those used by Edmond and Huh (2003) and Johnston et al. (2011) $\left(\mathrm{CaCO}_{3}=100 \mathrm{wt} \%\right.$; thickness $=200 \mathrm{~m}$ ). They can also be compared to those calculated from the model of Kent and Muttoni (2013) $\left(\mathrm{CaCO}_{3}=100 \mathrm{wt} \%\right.$; thickness of $\sim 240-270 \mathrm{~m}$ from 65 to
$50 \mathrm{Ma}$ ), who explicitly computed sediment thickness as a function of pelagic carbonate productivity and the timing of residence of the oceanic crust in the Neo-Tethyan equatorial belt zone. Note that sediment thickness may have been locally higher due to the presence of submarine fans or margin deposits such as carbonate platforms. However, paleogeographic reconstructions indicate that north of Greater India, the Paleocene-Eocene Neo-Tethys ocean was deep (Heine et al., 2004), favoring the predominance of pelagic deposition. For Arabia and Africa, the same conclusion can be drawn from palinspastic reconstructions of Barrier and Vrielynck (2008), who showed that only a small proportion of margin sediments were subducted during the Paleocene and the Eocene, compared to deep sediments.

\subsubsection{Continental crust and Indian margin sediments}

For subduction of northern Greater Indian passive margin sediments, a simplified passive continental margin geometry consisting of a sedimentary succession overlying the basement was designed (Fig. 2). Basement-sediment and the upper sediment interfaces were modeled using sigmoidal functions. Their shape was inspired from the geometry of the North American Atlantic passive margin (Watts and Thorne, 1984), which may have been a modern analogue to the pre-collisional northern Indian passive margin (Brookfield, 1993). Total length of the margin sediment succession was set to $600 \mathrm{~km}$, following Brookfield (1993) and in agreement with back-stripping reconstructions of Liu and Einsele (1994) and Guillot et al. (2008). Maximum sediment thickness was set to a mean value of $4 \mathrm{~km}$ (uncompacted), based on recent estimations of syn-rift/post-rift Neo-Tethyan margin sediment thicknesses of Sciunnach and Garzanti (2012). Although the lithology of the margin was variable, the proportion of carbonate sediments and organic matter may have been important (Beck et al., 1995; Liu and Einsele, 1994; Sciunnach and Garzanti, 2012). Average contents of 50 and $1 \mathrm{wt} \%$ were chosen for carbonate and organic carbon content, respectively. Uncompacted margin sediments were given a density of $2 \mathrm{t} \mathrm{m}^{-3}$ as calculated from data of Sciunnach and Garzanti (2012).

\subsection{Decarbonation efficiency of subducted materials}

\subsubsection{Oceanic crust and pelagic sediments}

In the "carbonate subduction factory" model, $\mathrm{CO}_{2}$ produced during oceanic subduction processes originates from deep metamorphic decarbonation of subducted crust and sediments (carbonate and organic matter), and is assumed to be released at volcanic arcs following partial melting of the subducting oceanic crust and metasomatism of the overlying mantle (Hilton et al., 2002; Gorman et al., 2006). This common statement was followed in the CSFM model (Fig. 3), therefore ignoring possible additional $\mathrm{CO}_{2}$ sources, in particular decarbonation of the overlying crust (Lee et al., 2013). 

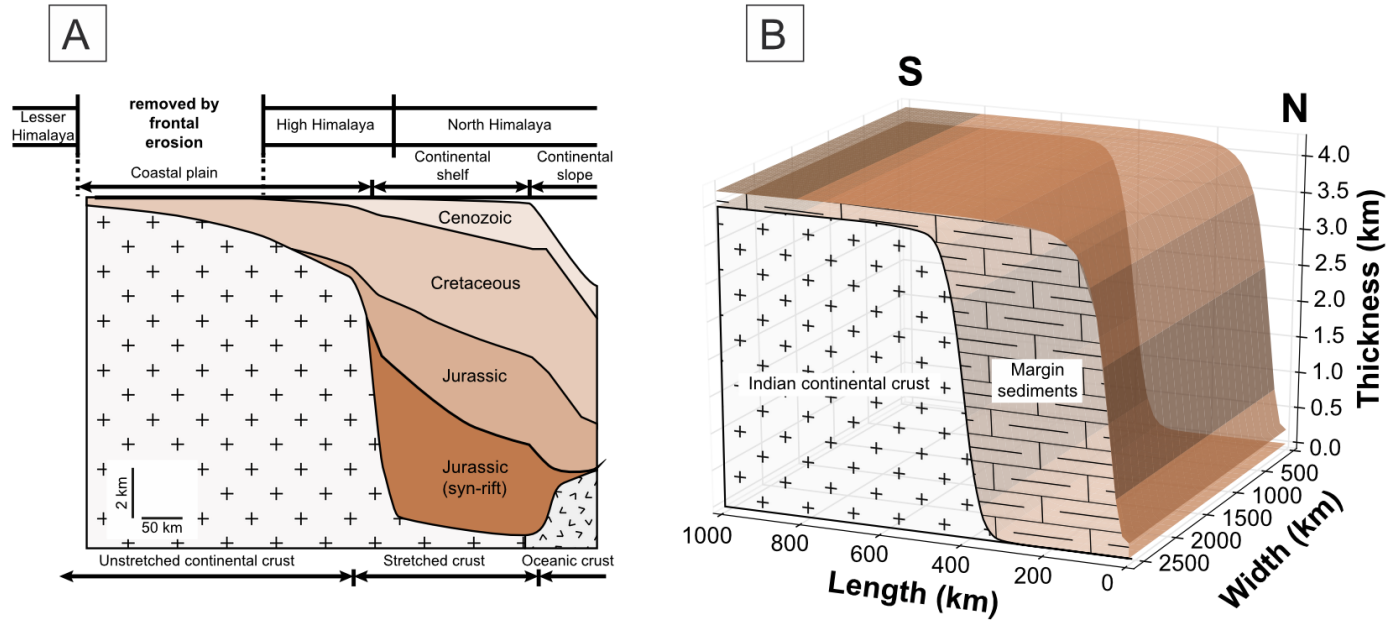

Figure 2. (a) Geometry of the Eastern US Atlantic coastal margin showing analogous positions for tectonic units of Indian passive margin (modified from Brookfield, 1993). (b) Geometry of Indian margin used in Carbonate Subduction Factory Model (CSFM).

The amount of $\mathrm{CO}_{2}$ released through arc volcanism was calculated as follows: first, for each time step, the total volume of subducting sediment and crust was computed. We assumed this volume to be similar to that encompassing metamorphic carbon loss in the sub-arc zone $(\sim 120 \pm 40 \mathrm{~km}$ depth; England and Katz, 2010) (i.e., no variation of volume during the subduction process before decarbonation). Then, the amount of $\mathrm{CO}_{2}$ emitted at the surface was calculated from arc decarbonation efficiency, defined as the ratio of the volcanic gas $\mathrm{CO}_{2}$ flux to the input of subducted carbon (e.g., Johnston et al., 2011) (Annex 2). Decarbonation efficiency values were based on modern decarbonation efficiencies calculated recently by Johnston et al. (2011) using a mass balance approach, and those computed by Gorman et al. (2006) based on thermodynamic modeling. Decarbonation efficiencies at sub-arc depth of Johnson et al. (2011) vary from 0.1 to $70 \%$ for 10 subduction trenches, with most values ranging between 18 and $54 \%$. They are quite similar to the mean values of Gorman et al. (2006) ( 16 and $\sim 63 \%$, if volcanic $\mathrm{CO}_{2}$ is derived from decarbonation at sub-arc depth only, or both at fore-arc and sub-arc depths, respectively), which are based on 41 subduction zones. We have retained values of 15 to $60 \%$. Note that such values exceed the one used by Kent and Muttoni (2013) to perform similar calculations (10\%), based on ${ }^{10} \mathrm{Be}$ data in arc volcanoes of Central America (Tera et al., 1986). Finally, the time lag between decarbonation at depth and gas emission at the surface was set to $2 \mathrm{Ma}$, averaging timescales of Turner (2002) (0.4 to $4 \mathrm{Ma}$ ).

\subsubsection{Continental crust and Indian margin sediments}

Due to the lack of aqueous fluids in continental crust, continental subduction zones are expected to be devoid of significant syn-subduction arc volcanism in the overlying plate (Zheng, 2012). Although volcanism may have continued in
Tibet after $50 \mathrm{Ma}$ (Ji et al., 2009; Rohrmann et al., 2012), in the model oceanic slab-related metamorphic decarbonation and magma generation was considered to last until the arrival of the continental lithosphere at sub-arc depth (i.e., $80 \mathrm{~km}$ ) (Fig. 3). Using preferred geometric parameters of Leech et al. (2005) for subduction of the Indian plate, this depth is reached $\sim 1.5$ to $2 \mathrm{Ma}$ after the initiation of continental subduction. Despite cessation of volcanic activity, subduction of continental margin sediments may have been associated with active $\mathrm{CO}_{2}$ degassing at springs or vents as a result of efficient metamorphic sediment decarbonation at $T>300^{\circ} \mathrm{C}$ (e.g., Becker et al., 2008; Evans et al., 2008). Kerrick and Caldeira (1993) suggested that limited collision-related prograde metamorphism of marly lithologies may induce a $\mathrm{CO}_{2}$ loss of $\sim 10 \mathrm{wt} \%$, equivalent to a decarbonation efficiency of $\sim 50 \%$ for sediments with a carbonate content of $50 \mathrm{wt} \%$ $\left(=22 \mathrm{wt} \% \mathrm{CO}_{2}\right)$. This value may represent an upper estimate as shown by thermodynamic modeling of Massonne (2010). Above-mentioned studies focus on collision rather than continental subduction, for which to our knowledge no estimations of $\mathrm{CO}_{2}$ outgassing fluxes or decarbonation efficiency are available. To avoid overestimations of $\mathrm{CO}_{2}$ production, we assumed that only limited margin sediment decarbonation may have occurred after the onset of continental subduction at low-grade conditions, with a 1 to $10 \mathrm{wt} \%$ efficiency. Time necessary for subducted margin material to reach the $300^{\circ} \mathrm{C}$ isotherm after the onset of continental subduction at $\sim 55-50 \mathrm{Ma}$ (corresponding to $25 \mathrm{~km}$ depth with a normal-subduction geothermal gradient of $15^{\circ} \mathrm{C} \mathrm{km}^{-1}$ ) was set to $0.5 \mathrm{Ma}$, as calculated with parameters of Leech et al. (2005). Circulation of $\mathrm{CO}_{2}$-rich fluids along large-scale collision-related thrust detachments has been proposed as an efficient way to promote degassing at the surface (e.g., Kerrick and Caldeira, 1993; Becker et al., 2008). Following Skelton (2011), who suggested that gas produced during low- 

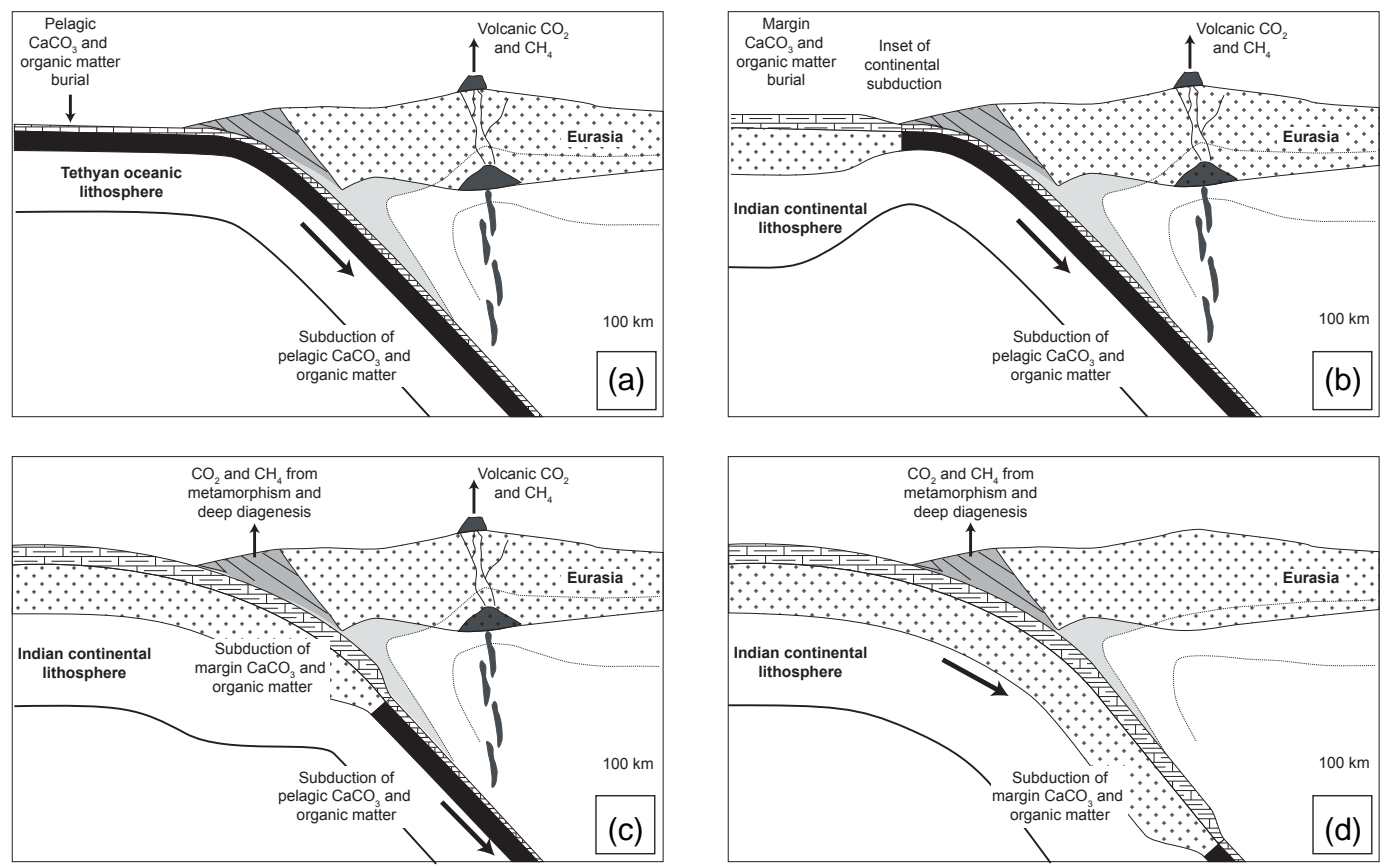

Figure 3. Sketches illustrating the carbon input and outputs considered in the model during subduction. (a) General sketch for subduction of oceanic crust and pelagic sediments (Africa, Arabia and India before Indian continental subduction). Carbon deposited as carbonate and organic carbon in pelagic sediments, as well as crustal carbonate, is partly recycled at sub-arc depth and incorporated in arc magmas. (b) Similar sketch at the inset of Indian continental subduction. (c) Subduction of northern Indian margin before it reaches sub-arc depth. Carbon originating from low-grade metamorphism of Indian margin sediments is partly released to the atmosphere, making additional greenhouse gas to that released at arc volcanoes. (d) Arc volcanism stops as Indian continental crust reaches sub-arc depth.

grade metamorphism may be rapidly released to the surface ( $\sim 4000 \mathrm{yr}$ ), we considered immediate release of $\mathrm{CO}_{2}$ to the atmosphere (Annex 2).

\subsection{Results}

\subsubsection{Tethyan subduction rate}

During the Paleocene (65 to $56 \mathrm{Ma}$ ), the mean subduction rate (i.e., all plates) has a constant value of $\approx 5.5 \mathrm{~cm} \mathrm{yr}^{-1}$ (Fig. 4a). Increased rates (up to $8.3 \mathrm{~cm} \mathrm{yr}^{-1}$ ) are computed between 56 and $53 \mathrm{Ma}$, before a gradual decrease to $3 \mathrm{~cm} \mathrm{yr}^{-1}$ at $35 \mathrm{Ma}$. India-Asia convergence, which reaches up to $16.7 \mathrm{~cm} \mathrm{yr}^{-1}$ at $53-52 \mathrm{Ma}$, exerts the main control on high early Cenozoic subduction rates.

\subsubsection{Greenhouse gas production}

It is important to note that decarbonation efficiencies may have strongly varied with time, depending particularly on the plate age and sediment thickness (Peacock, 2003; Connolly, 2005; Johnston et al., 2011). However, according to Johnston et al. (2011) the decarbonation efficiency is only roughly correlated with convergence (subduction) rate. Therefore, excess $\mathrm{CO}_{2}$ fluxes calculated at minimum $(15 \%)$ and maximum $(60 \%)$ efficiencies correspond to extreme scenarios that very likely encompass true excess $\mathrm{CO}_{2}$ fluxes related to Neo-Tethys closure.

\section{Without Indian continental subduction}

If Greater Indian continental subduction collision is not considered, $\mathrm{CO}_{2}$ production varies from $0.3-1.1 \times 10^{18}$ to $0.4-1.65 \times 10^{18} \mathrm{molCO}_{2} \mathrm{Ma}^{-1}$ (15-60\% efficiency, respectively) between 65 and $50 \mathrm{Ma}$ (Fig. 4b). This amounts up to $37 \%$ of the modern global outgassing rate $(\sim 4$ $10 \times 10^{18} \mathrm{molCO}_{2} \mathrm{Ma}^{-1}$; Berner, 2004). Highest possible values occur at a peak centered on the EECO (54-51 Ma). These flow rates exceed those computed before 65 and after $50 \mathrm{Ma}$. If subduction of the Indian plate alone was acting as the main driver of $\mathrm{CO}_{2}$ degassing, as proposed by Kent and Muttoni (2008), maximal $\mathrm{CO}_{2}$ production would reach $1.1 \times 10^{18} \mathrm{molCO}_{2} \mathrm{Ma}^{-1}$ from 54 to $50 \mathrm{Ma}$ (Fig. $4 \mathrm{c}$ ), corresponding to $11-27 \%$ of the modern outgassing rate.

\section{With Indian continental subduction}

Decarbonation of Greater Indian margin sediments, added to the last volumes of pelagic sediments at sub-arc depth, results in a peak of $\mathrm{CO}_{2}$ production $\sim 2 \mathrm{Ma}$ after the onset of continental subduction, considering a constant decar- 

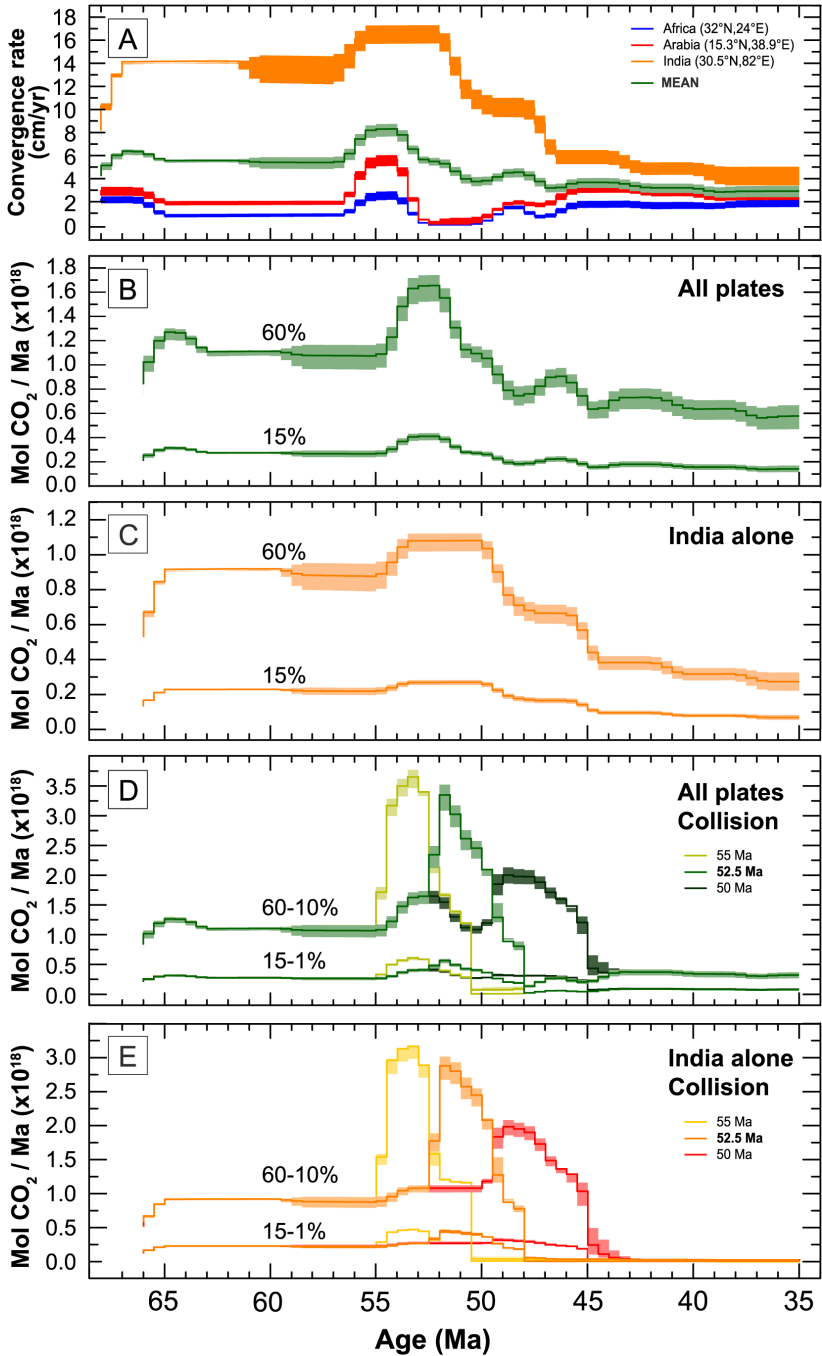

Figure 4. (a) Calculated mean Tethyan subduction rate over the period 65-35 Ma, compared with individual subduction rates of Africa, Arabia and India beneath Eurasia. Upper and lower limits of the shaded areas are maximum and minimum velocities, respectively, corresponding to points located on the western and eastern syntaxes of each plate. Rates calculated using rotation parameters of van Hinsbergen et al. (2011a, b). (b) Amount of $\mathrm{CO}_{2}$ produced by the subduction of the Tethys under Eurasia for the same period (green lines), using plate velocities calculated from van Hinsbergen et al. (2011a), for 15 and $60 \%$ efficiencies. Upper and lower limits of the shaded areas are maximum and minimum gas flux rates computed for each efficiency, respectively. (c) Same as (b) but for Indian only. (d) Same as (b) but including Indian margin subduction at 55, 52.5 and 50 Ma. (e) Same as (d) but for India only.

bonation efficiency (Fig. 4d). In our model, continental subduction must start at $52.5 \mathrm{Ma}$ (consistent for example with stratigraphic arguments of Najman et al., 2010 and paleomagnetic arguments of Huang et al., 2015b) for maximum $\mathrm{CO}_{2}$ emissions to occur at $\sim 51 \mathrm{Ma}$, i.e. coeval to maximum recorded temperatures during the EECO (Zachos et al., 2008). In this case, $\mathrm{CO}_{2}$ degassing flow rates are in the range $0.6-3.35 \times 10^{18} \mathrm{molCO}_{2} \mathrm{Ma}^{-1}(1 / 15-10 / 60 \%$ efficiencies for margin/pelagic sediments, respectively), corresponding to $6-84 \%$ of the modern $\mathrm{CO}_{2}$ outgassing rate. A $55 \mathrm{Ma}$ age for the inset of continental subduction results in even higher production $\left(0.65-3.7 \times 10^{18} \mathrm{molCO}_{2} \mathrm{Ma}^{-1}\right)$ although on a peak centered at $53.5 \mathrm{Ma}, \sim 2 \mathrm{Ma}$ before maximum recorded paleotemperatures (Fig. 4d). In contrast, late subduction $(50 \mathrm{Ma})$ results in the presence of two smaller peaks: the first one (54-52 Ma) only relates to decarbonation of subducted pelagic sediments whereas the second (48-46 Ma) largely results from decarbonation of margin sediments $\left(0.32-2 \times 10^{18} \mathrm{molCO}_{2} \mathrm{Ma}^{-1}\right.$ for $1-$ $10 \%$ efficiency, respectively) (Fig. 4d). If the Indian plate alone is considered $(52.5 \mathrm{Ma}), \mathrm{CO}_{2}$ production reaches $0.46-3 \times 10^{18} \mathrm{molCO}_{2} \mathrm{Ma}^{-1}(1 / 15-10 / 60 \%$ efficiencies for margin and/or pelagic sediments, respectively) at $\sim 52$ $51 \mathrm{Ma}$, amounting up to $75 \%$ of the modern outgassing rate (Fig. 4e).

\section{Modeling the impact of neothetys closure}

To test the influence of calculated excess $\mathrm{CO}_{2}$ fluxes on $\mathrm{Pa}$ leocene/Early Eocene climate, we carried out simulations using the GEOCLIM model (Donnadieu et al., 2004; Goddéris et al., 2008). This model couples a 3-D general circulation model (GCM) called FOAM (Jacob, 1997) to a box model of geological carbon-alkalinity cycles called COMBINE (Goddéris and Joachimski, 2004). The GCM FOAM is used in mixed-layer mode, where atmosphere is linked to a $50 \mathrm{~m}$ mixed-layer ocean, which parameterizes heat transport through diffusion, in order to reduce computation time (one GEOCLIM simulation needs up to 12 GCM simulations). This GCM is forced by a large range of $p \mathrm{CO}_{2}(200$ up to $4200 \mathrm{ppmv}$ ) to generate an offline catalogue of continental air temperature and continental runoff with a spatial resolution of $7.5^{\circ}$ long $\times 4.5^{\circ}$ lat. For each corresponding atmospheric $p \mathrm{CO}_{2}$ value, the GEOCLIM model calculates the temperature and the runoff of each grid cell through a linear interpolation procedure from the climatic catalogue. This procedure is repeated until a steady-state is reached that corresponds to a stable atmospheric $\mathrm{CO}_{2}$ and temperature. The model uses an ocean geometry divided into two polar oceans (including a photic zone and a deep ocean reservoir), a low- to mid-latitude ocean (including a photic zone, a thermocline and a deep ocean reservoir), two epicontinental seas (both with a photic zone and a deep epicontinental reservoir) and the atmosphere. A full description of GEOCLIM and its components COMBINE and FOAM can be found in Goddéris and Joachimski (2004) and Donnadieu et al. (2006).

\subsection{GEOCLIM simulations}

We first calculated the steady-state $p \mathrm{CO}_{2}$, assuming that the total $\mathrm{CO}_{2}$ consumed by continental silicate rocks weather- 
ing equals the total solid Earth $\mathrm{CO}_{2}$ degassing flux (Walker et al., 1981). Due to the non-consensus about the Earth degassing rate for the last $200 \mathrm{Ma}$, the degassing flux was assumed constant and fixed at a modern value of $6.8 \times 10^{18} \mathrm{molCO}_{2} \mathrm{Ma}^{-1}$, which is required in the model to balance the global consumption through the weathering of silicate lithologies (Donnadieu et al., 2006). Each terrestrial grid was prescribed a similar lithology, in which basalt weathering reaches a $30 \%$ contribution of the total silicate weathering flux taken at present day (Dessert et al., 2003) (similar to UNI configuration of Lefebvre et al., 2013). Lefebvre et al. (2013) have shown that with this configuration steady-state $p \mathrm{CO}_{2}$ is similar at 65,52 and $30 \mathrm{Ma}$ (320-350 ppm), despite variations in paleogeography. An Early Eocene (52 Ma) paleogeographic reconstruction was thus used in the simulation, which runs from 65 to $40 \mathrm{Ma}$. Land-ocean configuration was built from a synthesis of paleomagnetic data and geologic constraints (Besse and Courtillot, 2002; Dercourt et al., 1993). Obliquity and radiation solar constant were assumed to equal present-day values.

The main geological forcing tested in the simulation is the additional $\mathrm{CO}_{2}$ fluxes calculated from CFSM. $\mathrm{CO}_{2}$ fluxes of Kent and Muttoni (2013) have also been tested, using decarbonation efficiencies of 15 and $60 \%$ in addition to the original value of $10 \%$ proposed by the authors. Computed $\mathrm{CO}_{2}$ outgassing rates resulting from Neo-Tethys closure were integrated to GEOCLIM, in an age step of $1 \mathrm{Ma}$.

\section{2 $p \mathrm{CO}_{2}$ evolution during the LPEE and the EECO}

If minimum decarbonation efficiency $(15 \%)$ is considered, $p \mathrm{CO}_{2}$ increase following excess $\mathrm{CO}_{2}$ flux is negligible (Fig. 5c). For example, the addition of continental subduction, which results in higher $\mathrm{CO}_{2}$ fluxes, allows reaching maximum $p \mathrm{CO}_{2}$ of only $360-365 \mathrm{ppm}$ at $51 \mathrm{Ma}$ (i.e. close to steady state values).

If maximum decarbonation efficiency $(60 \%)$ is considered, calculated excess $\mathrm{CO}_{2}$ fluxes lead to $p \mathrm{CO}_{2}$ of $430-$ $450 \mathrm{ppm}$ from 65 to $54 \mathrm{Ma}$ (Fig. 5c). Without continental subduction, between 54 and $51 \mathrm{Ma}, p \mathrm{CO}_{2}$ increases up to $500-550 \mathrm{ppm}$. It then decreases to steady state $p \mathrm{CO}_{2}$ values from $48 \mathrm{Ma}$. With continental subduction, $p \mathrm{CO}_{2}$ can reach much higher values. In the preferred scenario (initiation of continental subduction at $52.5 \mathrm{Ma}), p \mathrm{CO}_{2}$ strongly increases at $54 \mathrm{Ma}$ up to reach a peak of $\sim 770 \mathrm{ppm}$ at $51.5 \mathrm{Ma}$. It then decreases to values close to steady state at $47 \mathrm{Ma}$ (Fig. 5c). If continental subduction begins at $55 \mathrm{Ma}$, a peak of similar amplitude (770 ppm) occurs at $53 \mathrm{Ma}$ (Fig. $5 \mathrm{~d})$. In contrast, a $50 \mathrm{Ma}$ age for the initiation of subduction results in two peaks of smaller amplitude, with $p \mathrm{CO}_{2}$ values of $\sim 520$ and $\sim 570 \mathrm{ppm}$ at $\sim 52$ and $48 \mathrm{Ma}$, respectively (Fig. 5 d).

Using excess $\mathrm{CO}_{2}$ fluxes of Kent and Muttoni (2013) leads to low atmospheric $\mathrm{CO}_{2}$ concentrations whatever chosen decarbonation efficiencies (10, 15 or $60 \%$ ) (Fig. 5e). Following an increasing trend of excess $\mathrm{CO}_{2}$ flux, $p \mathrm{CO}_{2}$ progres- sively increases from $330-340-445 \mathrm{ppm}$ at 65 to $335-345-$ $475 \mathrm{ppm}$ at $50 \mathrm{Ma}(10-15-60 \%$ efficiency, respectively). It then rapidly decreases to values lower than $335 \mathrm{ppm}$ after $48 \mathrm{Ma}$.

\section{Discussion}

\subsection{Impact of Neo-Tethys closure on Paleocene-Eocene climate}

It has long been suggested that Paleocene/Eocene warming was not due to an increase of mantle degassing, calling for additional sources of atmospheric $\mathrm{CO}_{2}$ (Engebretson et al., 1992; Kerrick and Caldeira, 1993; Hilting et al., 2008; Van der Meer et al., 2014). Kerrick and Caldeira (1993) first showed, on the basis of a simple carbon cycle model that the minimal value of additional $\mathrm{CO}_{2}$ necessary to drive climate warming during the LPEE and the $\operatorname{EECO}\left(\geq 1^{\circ} \mathrm{C}\right)$ may have been close to $\sim 10^{18} \mathrm{molCO}_{2} \mathrm{Ma}^{-1}$. More recently, Lefebvre et al. (2013) used the GEOCLIM model to calculate that a higher flux of $\sim 3.4 \times 10^{18} \mathrm{molCO}_{2} \mathrm{Ma}^{-1}$, corresponding to a $50 \%$ increase of global $\mathrm{CO}_{2}$ degassing rate, was needed to reach a $p \mathrm{CO}_{2}$ value of $930 \mathrm{ppm}$ consistent with geochemical proxies compiled by Beerling and Royer (2011).

Estimations of $\mathrm{CO}_{2}$ outgassing resulting from Neo-Tethys closure during the Cretaceous and the Paleogene have been previously proposed by Edmond and Huh (2003), Johnston et al. (2011) and Kent and Muttoni (2013). Values calculated from data of Kent and Muttoni (2013) $\left(<1.3 \times 10^{17} \mathrm{molCO}_{2} \mathrm{Ma}^{-1}\right.$ from 80 to $\left.50 \mathrm{Ma}\right)$ fall largely below those required by modeling of Lefebvre et al. (2013) to reach estimated $p \mathrm{CO}_{2}$, largely because of their choice of limited decarbonation efficiency during subduction (10\%). In contrast, estimations of Edmond and Huh (2003) and Johnston et al. (2011) vary from 0.5 to $4 \times 10^{18} \mathrm{molCO}_{2} \mathrm{Ma}^{-1}$ for the entire Tethyan arc. According to results of Lefebvre et al. (2013), the higher range of these values should allow to sustain a warm climate during the Paleocene and the lower Eocene. However, excess $\mathrm{CO}_{2}$ flux calculations of Edmond and Huh (2003) and Johnston et al. (2011) represent only average values based on simple assumptions such as a constant subduction rate for the entire Upper Cretaceous-Lower Cenozoic. Nevertheless, these estimates are generally higher than those calculated using CFSM. We rather suggest that between 65 and $\sim 55 \mathrm{Ma}$ (i.e., before the oldest possible age of Indian continental subduction), Neo-Tethys closure may have released less than $\sim 10^{18} \mathrm{molCO}_{2} \mathrm{Ma}^{-1}$, in particular owing to subduction rates lower than the one used by Edmond and Huh (2003) and Johnston et al. (2011) ( 5.5 vs. $8 \mathrm{~cm} \mathrm{yr}^{-1}$, respectively). Using the GEOCLIM model, $\mathrm{CO}_{2}$ outgassing values obtained with maximum decarbonation efficiency $(60 \%)$ allow to reach a $p \mathrm{CO}_{2}$ of $\sim 430 \mathrm{ppm}$, which is in agreement with proxies for the Early Paleocene (65$60 \mathrm{Ma}$ ) (Beerling and Royer, 2011) (Fig. 5c). Therefore, our modeling suggests that high decarbonation efficiency was a 

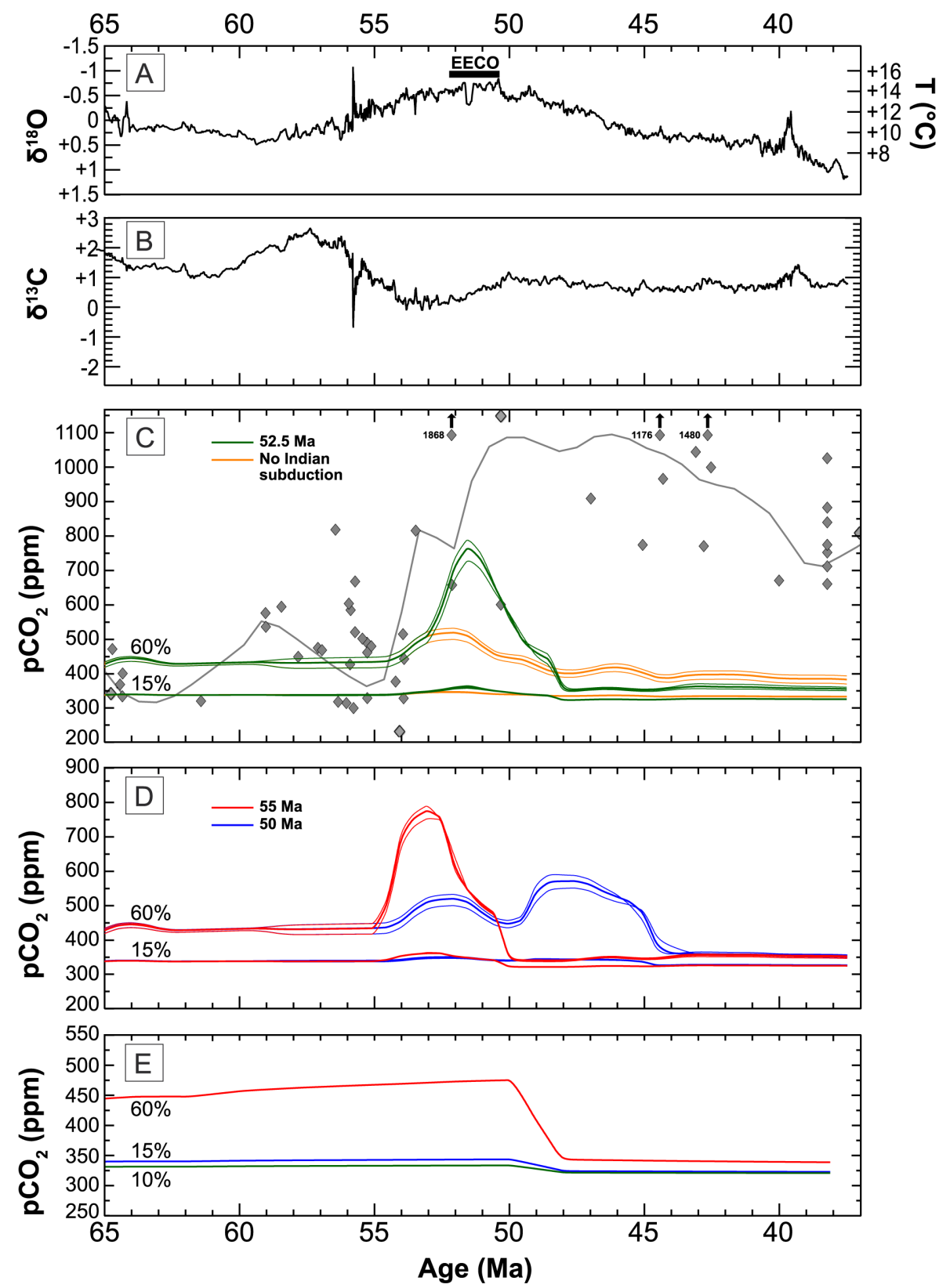

Figure 5. (a, b) Global oceanic benthic $\delta^{18} \mathrm{O}$ (a) and $\delta^{13} \mathrm{C}$ (b) foraminiferal compilation based on data from Cramer et al. (2009). Data were smoothed using a 10-point running average. Temperatures calculated from $\delta^{18} \mathrm{O}$ values assume an ice-free world (after Komar et al., 2013). (c) GEOCLIM modeling results of atmospheric $p \mathrm{CO}_{2}$ resulting from excess $\mathrm{CO}_{2}$ release associated with Neo-Tethys closure using plate velocities calculated from van Hinsbergen et al. (2011a), for 15 and $60 \%$ decarbonation efficiencies. Orange curves assume no Indian continental subduction, green lines correspond to an initiation of Indian continental subduction at 52.5 Ma. Individual (gray diamonds) and mean (black line) atmospheric $p \mathrm{CO}_{2}$ recorded by paleoproxies are also shown (from Beerling and Royer (2011)). Black arrows and associated number refer to $p \mathrm{CO}_{2}$ values too high to be displayed. (d) Same as (c) but for an initiation of Indian continental subduction at $55 \mathrm{Ma}$ (red curves) and $50 \mathrm{Ma}$ (blue curves). (e) GEOCLIM modeling results of atmospheric $p \mathrm{CO}_{2}$ resulting from excess $\mathrm{CO}_{2}$ release as calculated from data of Kent and Muttoni (2013) using efficiencies of 10, 15 and $60 \%$.

prerequisite for the "carbonate subduction factory" to have a significant impact on global climate at that time. In addition, GEOCLIM seems unable to explain the onset of PaleoceneEocene warming at $58 \mathrm{Ma}$, coevally to an increase of at- mospheric $p \mathrm{CO}_{2}$ (Beerling and Royer, 2011) (Fig. 5a, b, c). Similar conclusions can be drawn from climatic simulations performed with excess $\mathrm{CO}_{2}$ fluxes of Kent and Muttoni (2013), even using a decarbonation efficiency of $60 \%$ 
(Fig. 5e). In that case, $p \mathrm{CO}_{2}$ only steadily increases during the Paleocene and remains lower than values suggested by proxies (Fig. 5c).

A more significant contribution of Neo-Tethyan closure to global warming may have occurred close to the EECO ( 52-49 Ma), owing in particular to an increase of the Indian subduction rate (Fig. 4a). This contribution is also conditioned by maximum decarbonation efficiency, and by the onset of Indian continental subduction at $\sim 52 \mathrm{Ma}$. With these two conditions fulfilled, the model allows to reach $p \mathrm{CO}_{2}$ values lower than, but close to proxy ones $(<850 \mathrm{ppm}$ vs. $\sim 1000 \mathrm{ppm}$, respectively) (Fig. 5b). Based on calculations of climate sensitivity to atmospheric $\mathrm{CO}_{2}$ of GEOCLIM performed by Godderis et al. (2014) $\left(2.4^{\circ} \mathrm{C}\right.$ for a $p \mathrm{CO}_{2}$ doubling at $52 \mathrm{Ma}$ ), they may have resulted in a related global atmospheric temperature increase of $\sim 2{ }^{\circ} \mathrm{C}$ compared to the Paleocene. In contrast, if India-Asia continental subduction occurred much later (i.e., equivalent to no collision), Neo-Tethys contribution to the EECO remained negligible, even with a decarbonation efficiency of $60 \%$ (Fig. 5c). Calculations performed with input data of Kent and Muttoni (2013) lead to the same interpretation for the Early Eocene (Fig. 5e).

Finally, our study allows to clearly moderate the impact of the Neo-Tethyan "carbonate subduction factory" on Paleocene-Eocene greenhouse, at odds with Edmond and Huh (2003), Johnston et al. (2011) and Kent and Muttoni (2008), but in accordance with recent conclusions of Kent and Muttoni (2013) and Lee et al. (2013). As a consequence, the strong decrease of $\mathrm{CO}_{2}$ production after India-Asia collision was not a driver of $p \mathrm{CO}_{2}$ decrease and global cooling recorded after the late Eocene (Kent and Muttoni, 2013).

\subsection{Potential additional sources of atmospheric carbon dioxide}

\subsubsection{Large igneous provinces}

Since the role of Neo-Tethys closure on the onset of the LPEE and the EECO has likely been limited, other sources of excess greenhouse gases should be called for. These should ideally explain the decrease of marine and terrestrial $\delta^{13} \mathrm{C}$ during the LPEE, and its slight increase during the EECO (Zachos et al., 2001) (Fig. 5a). Numerous geological explanations have previously been postulated for the entire early Cenozoic greenhouse, among which a flare up in the activity of igneous provinces is the most common (e.g., Eldhom and Thomas, 1993; Reagan et al., 2013). Reagan et al. (2013) presented a review of Late Paleocene to Early Eocene magmatism, characterized by the significant activity of at least three major igneous provinces: the North Atlantic Igneous Province, the Siletzia terrane of the northwestern United States and the Yakutat block in southern Alaska. Added to enhanced activity of Neo-Tethys and eastern Pacific subduction-related volcanism, Reagan et al. (2013) concluded for an overall excess $\mathrm{CO}_{2}$ production of $\sim 2.3 \times 10^{18} \mathrm{molCO}_{2}$ for the late Paleocene-Early Eocene period. Even though this value may appear important, it encompasses a time duration of several million years. Assuming a 10 Ma duration for significant magmatism (see Reagan et al. (2013), Fig. 6), the calculated excess $\mathrm{CO}_{2}$ flow rate falls to only $\sim 2.3 \times 10^{17} \mathrm{molCO}_{2} \mathrm{Ma}^{-1}$ on average, 1 order of magnitude below fluxes necessary to reach a $p \mathrm{CO}_{2}$ comparable to proxies using the GEOCLIM model. This value can be compared to that of Eldholm and Thomas (1993), who calculated that more than $2.3 \times 10^{18} \mathrm{molCO}_{2}$ may have been released to the atmosphere by the NAIP only, from 58 to $52 \mathrm{Ma}$ (revised to 61-53 Ma by Menzies et al., 2002), corresponding to a flux of $\sim 3 \times 10^{17} \mathrm{molCO}_{2} \mathrm{Ma}^{-1}$. We infer, on the base of GEOCLIM modeling, that the effect of enhanced magmatic activity on LPEE warming and the EECO may also have been limited, unless related fluxes have been severely underestimated in the literature. As discussed later, this conclusion is consistent with previous studies of carbon cycle dynamics during the early Cenozoic (e.g., Hilting et al., 2008; Komar et al., 2013).

\subsubsection{Metamorphic decarbonation}

Lee et al. (2013) argued that the decarbonation of platform carbonates stored on the continental upper plate during subduction-related magmatism may have been far more efficient in driving early Cenozoic greenhouse than the activity of igneous provinces or of the "subduction factory". Lee et al. (2013) calculated that global $\mathrm{CO}_{2}$ degassing could have reached 3.7-5.5 times the present day value from $\sim 140$ to $50 \mathrm{Ma}$, making $2.2-3.7 \times 10^{19} \mathrm{molCO}_{2} \mathrm{Ma}^{-1}$ for a present day value of $6.8 \times 10^{18} \mathrm{molCO}_{2} \mathrm{Ma}^{-1}$ (as calculated with GEOCLIM). Cooling initiation during the late Eocene would then have resulted from a transition from a continentaldominated to an island arc-dominated world ca. $52 \mathrm{Ma}$. The EECO would represent a "last spurt of $\mathrm{CO}_{2}$ production associated with an Eocene magmatic flare-up in western North America", based on previous work of Nesbitt et al. (1995) and Kerrick and Caldeira (1998). In light of the GEOCLIM model, we argue that $\mathrm{CO}_{2}$ fluxes of Lee et al. (2013) are clearly overestimated for the EECO, as $p \mathrm{CO}_{2}$ close to proxies would be obtained for excess fluxes lower by approximately 1 order of magnitude. If they are applied to the EECO, fluxes calculated by Kerrick and Caldeira (1998) for the 60$55 \mathrm{Ma}$ period $\left(3 \times 10^{18} \mathrm{molCO}_{2} \mathrm{Ma}^{-1}\right)$ seem more reasonable. Similar to the decarbonation of pelagic carbonate sediments, crustal decarbonation related to magmatic or metamorphic events should lead to a positive shift of exogenic $\delta^{13} \mathrm{C}$ (Lee et al., 2013), in agreement with proxies for the EECO. In contrast, the LPEE was characterized by a related negative shift in $\delta^{13} \mathrm{C}$ (Zachos et al., 2001), suggesting additional or alternate sources of excess isotopically light $\mathrm{CO}_{2}$. 


\subsubsection{Organic carbon sources}

Several authors have thus proposed organic carbon $\left(\mathrm{C}_{\mathrm{org}}\right)$ to be a significant source of excess $\mathrm{CO}_{2}$ during the LPEE and/or the EECO, mostly based on carbon cycle models (e.g., Beck et al., 1995; Kurtz et al., 2003; Hilton et al., 2008; Kroeger and Funnel, 2012; Komar et al., 2013). The importance of organic carbon dynamics was clearly highlighted by Hilting et al. (2008), who used a carbon cycle model tuned with marine $\delta^{13} \mathrm{C}$ data to calculate Paleocene and Eocene $p \mathrm{CO}_{2}$ values. These authors managed to reproduce $p \mathrm{CO}_{2}$ values globally consistent with observations, even though background volcanic-metamorphic $\mathrm{CO}_{2}$ degassing was kept constant. According to their simulation, large changes in $p \mathrm{CO}_{2}$ (and thus, temperature) may occur independently of the endogenic carbon cycle. Similar conclusions were drawn by Komar et al. (2013) on the basis of coupled LOSCAR-GEOCARB carbon cycle modeling. They showed that a mantellic source of excess $\mathrm{CO}_{2}$ during the LPEE would have led to a deepening of the CCD much more important that evidenced from observations. Although based on a different approach, this conclusion is in good accordance with our suggestion of a moderate impact of LIPs on the LPEE (and the EECO). Instead, Komar et al. (2013) proposed that perturbations of the carbon cycle observed during the LPEE were likely controlled by a decrease of net organic carbon burial, either through increased $\mathrm{C}_{\text {org }}$ oxidation, or through decreased $\mathrm{C}_{\text {org }}$ burial. Suitable sources of organic carbon to the exogenic system include methane hydrates, which may have accumulated in marine sediments during the early Paleocene, and collapsed during the LPEE (Komar et al., 2013), terrestrial organic matter previously accumulated in swamps (Kurtz et al., 2003), or important reservoir petroleum generation (Kroeger and Funnel, 2012). However, the timing of maximum hydrocarbon production calculated by Kroeger and Funnel (2012) likely occurred during the EECO, which is hardly reconcilable with coeval increase in marine $\delta^{13} \mathrm{C}$ unless net $\mathrm{C}_{\text {org }}$ burial was significantly higher than during the LPEE (e.g., Kurtz et al., 2003). Finally, Beck et al. (1995) postulated that Neo-Tethyan marine organic matter accumulated on Eurasian and Greater Indian margins may have been oxidized during India-Asia collision and subsequent exhumation, provided collision occurred no later than $\sim 60 \mathrm{Ma}$. About $1.6 \times 10^{18} \mathrm{molC} \mathrm{Ma}^{-1}$ may have been released during the first $4 \mathrm{Ma}$ of the LPEE, enough to explain the concurrent negative shift in $\delta^{13} \mathrm{C}$. Using our model, we calculate that the organic carbon contained within Greater Indian margin alone $\left(\sim 3.8 \times 10^{6} \mathrm{~km}^{3}\right)$ amounts to $\sim 8 \times 10^{18} \mathrm{molC}$ (for a sediment organic carbon content of $1 \mathrm{wt} \%$ ), corresponding to a flux of $\sim 2 \times 10^{18} \mathrm{molC} \mathrm{Ma}^{-1}$ (i.e., close to estimates of Beck et al. (1995)) if all $\mathrm{C}_{\text {org }}$ was oxidized during exhumation. This was probably not the case, and our estimate is likely overestimated. Nevertheless, it shows that oxidation of Neo-Tethyan marine $\mathrm{C}_{\text {org }}$ may have contributed to the LPEE if collision occurred earlier than assumed in our model (e.g.,
Hu et al., 2015), to an extent that deserves to be quantified more accurately in future studies.

In contrast to the LPEE, the rise in marine $\delta^{13} \mathrm{C}$ from 52.5 to $50 \mathrm{Ma}$ suggests that the EECO was characterized by increased net organic carbon burial (as proposed by Komar et al. (2013) with the methane hydrate hypothesis), or as we test in this paper, by the addition of excess $\mathrm{CO}_{2}$ derived from one or several sources with heavier $\delta^{13} \mathrm{C}$ signatures. Both explanations need to be reconciled with recent observations that silicate weathering may have been reduced during the EECO, as discussed below.

\subsection{Are modeled silicate weathering fluxes overestimated for the EECO?}

Most carbon cycle models agree that during the Early Eocene volcanic degassing alone was insufficient to sustain the high $p \mathrm{CO}_{2}$ values required by proxies, due to important weathering rates at that time (e.g., Berner, 2006; Lefebvre et al., 2013; Komar et al., 2013). For example, Berner (2006) found, based on the time evolution of seawater ${ }^{87} \mathrm{Sr} /{ }^{86} \mathrm{Sr}$ that weathering was mainly controlled by increased basaltic alteration, resulting in a $p \mathrm{CO}_{2}$ of $\sim 700 \mathrm{ppm}$ at $50 \mathrm{Ma}$, i.e. lower than observations ( $\sim 1000 \mathrm{ppm})$. Indeed, decreasing of seawater $\mathrm{Sr}$ isotopic signature during the Paleocene and the Early Eocene is consistent with the alteration of igneous provinces such as the Deccan Traps or the NAIP (Hoddell et al., 2007). In detail, most paleogeographic reconstructions show that the highly weatherable Deccan traps reached the equatorial humid belt (between $5^{\circ} \mathrm{S}$ and $5^{\circ} \mathrm{N}$ ), where weathering is maximum, at $\sim 55 \mathrm{Ma}$, with a maximum area of between $\sim 50$ and $\sim 35 \mathrm{Ma}$ (Dercourt et al., 1993; Besse and Courtillot, 2002; Van Hinsbergen et al., 2011a, 2012). Accordingly, taking explicitly into account the impact of paleogeography on the long-term carbon cycle as done by the GEOCLIM model has led Lefebvre et al. (2013) to suggest that the EECO was characterized by high weathering rates related to weathering of the Deccan traps. As a consequence, the model calculates a very low equilibrium $p \mathrm{CO}_{2}$ of $340 \mathrm{ppm}$ at that time. Calculations of Kent and Muttoni (2013) also pointed to an increase of silicate weathering, and thus of $\mathrm{CO}_{2}$ consumption during the LPEE and the EECO due to the arrival of Greater India in the equatorial humid belt at that time.

Even though most models and reconstructions seem to agree with the hypothesis of increased weathering during the Early Eocene, several proxy-based observations rather suggest that silicate weathering may have been reduced specifically during the EECO. The first one is based on the estimation of the carbonate compensation depth (CCD) during the Paleogene (Hancock et al., 2007; Leon-Rodriguez and Dickens, 2010; Pälike et al., 2012; Slotnick et al., 2014). During the LPEE, deep-sea carbonate records show a progressive deepening of the CCD that can be attributed to enhanced alkalinity supply to the oceans as a result of enhanced weather- 
ing (Komar et al., 2013). During the EECO, high $p \mathrm{CO}_{2}$ values $(\sim 1000 \mathrm{ppm})$ similarly should have sustained high silicate weathering and thus favored a deep position of the CCD. In contrast, available records suggest its strong shoaling at that time (Pälike et al. 2012; Slotnick et al., 2014), which according to Komar et al. (2013) hardly conforms to the intense weathering deduced form carbon cycle models. However, previous GEOCLIM modeling showed that a constant silicate weathering flux does not mean a fixed $p \mathrm{CO}_{2}$ (and thus a fixed CCD), due to the major role played by continental configuration on $p \mathrm{CO}_{2}$ values (Donnadieu et al., 2006). The second observation is based on $\delta^{7} \mathrm{Li}$ chemistry of Paleocene and Eocene marine sediments, compiled by Misra and Froelich (2012). These authors argued that $\mathrm{Li}$ isotopes allow discriminating between periods of high tectonic uplift associated with important physical and chemical weathering, and periods of low alteration (Froelich and Misra, 2014). According to Froelich and Misra (2014), the LPEE and the EECO were characterized by slow weathering rates, as shown by a low and constant $\delta^{7} \mathrm{Li}$ trend. This strong discrepancy with previous interpretations is attributed to the absence of continental reliefs at that time, preventing significant weathering of uplifted, fresh silicate rocks. According to Froelich and Misra (2014), only moderate additional $\mathrm{CO}_{2}$ may have allowed increasing $p \mathrm{CO}_{2}$ and global temperature up to the end of the EECO. Note that for the LPEE, this interpretation is in contradiction with that of Komar et al. (2013) based on the CCD. In addition, recent modeling of Vigier and Godderis (2015) suggests that the oceanic $\delta^{7} \mathrm{Li}$ record of the Early Eocene could equally be explained by intense soil production rates (i.e, intense chemical weathering). These contradictory observations show that the intensity of silicate weathering during the LPEE and the EECO still suffers from strong uncertainties, as already highlighted by Kent and Muttoni (2013). Additional proxy-based observations are thus needed to calibrate weathering rate values obtained from models, which for example still lack the explicit integration of uplift on carbon cycle evolution (Lefebvre et al., 2013).

\section{Conclusions}

In order to test the role that Neo-Tethys closure may have exerted on warm Paleocene/Early Eocene climate through $\mathrm{CO}_{2}$ degassing at arc volcanoes, we have calculated the volume of buried pelagic sediments and associated volcanic $\mathrm{CO}_{2}$ release during the LPEE and the EECO, and its impact on atmospheric $p \mathrm{CO}_{2}$ and atmospheric temperature at that time. To do so, we have applied most recently published convergence rate parameters and decarbonation efficiencies to a simplified Neo-Tethyan geometry, and integrated calculated excess $\mathrm{CO}_{2}$ fluxes in a state-of-the-art carbon cycle model (GEOCLIM).

We show that Neo-Tethys closure was able to bury significant volumes of pelagic sediments at that time. The inset of Indian continental subduction at 55-50 Ma may have potentially given rise to important volumes of excess $\mathrm{CO}_{2}$, through decarbonation of thick margin sediment accumulations. However, GEOCLIM modeling demonstrates that these volumes do not generally allow reaching $p \mathrm{CO}_{2}$ (and thus temperatures) as high as those inferred from geochemical proxies. Atmospheric $\mathrm{CO}_{2}$ concentration may have only been able to reach significantly high values during the EECO (up to $770 \mathrm{ppm}$ ), but only if decarbonation efficiency was at its maximum at that time. This finding leads us to temper the impact of Neothetys closure on the LPEE and the EECO, calling for additional sources of excess $\mathrm{CO}_{2}$.

Among these, GEOCLIM modeling suggests that in light of available published data, the volume of $\mathrm{CO}_{2}$ released by Large Igneous Province volcanism was 1 order of magnitude too low to have had a significant impact on climate during the Paleocene and the Early Eocene. Other recently proposed mechanisms of $\mathrm{CO}_{2}$ release such as a decrease of net organic carbon burial may have been more efficient in driving Paleocene-Eocene warming.

Finally, an alternate explanation may be that $\mathrm{CO}_{2}$ consumption may have been lower than suggested by carbon cycle models, calling for a better calibration of early Cenozoic weathering rates. 


\section{Appendix A}

For each plate, subduction rates at each time step were corrected for convergence obliquity related to the orientation of the subduction trench using spherical trigonometric equations of the following form:

Rate $_{\text {corr }}=\frac{\tan ^{-1}(\tan A \cdot \cos B)}{t_{2}-t_{1}}$

with

$$
\begin{aligned}
& A= R_{\mathrm{E}} \cdot \cos ^{-1}\left(\sin \varphi_{1} \cdot \sin \varphi_{2}+\cos \left(\lambda_{1}-\lambda_{2}\right)\right. \\
&\left.\cdot \cos \varphi_{1} \cdot \cos \varphi_{2}\right) \\
& B= \tan ^{-1} \\
&\left(\frac{\sin \left(\lambda_{2}-\lambda_{1}\right) \cdot \cos \varphi_{2}}{\cos \varphi_{1} \cdot \sin \varphi_{2}-\sin \varphi_{1} \cdot \cos \varphi_{2} \cdot \cos \left(\lambda_{2}-\lambda_{1}\right)-\left(B_{t}-90^{\circ}\right)}\right),
\end{aligned}
$$

where Rate corr $_{\text {is }}$ the corrected rate, $\left(\varphi_{1}, \lambda_{1}\right)$ and $\left(\varphi_{2}, \lambda_{2}\right)$ the lat/long decimal coordinates of two successive points, $t_{2}-t_{1}$ the time step $(0.5 \mathrm{Ma}), R_{\mathrm{E}}$ the Earth radius $(6378.1 \mathrm{~km})$ and $B_{t}$ the trench bearing. Based on paleogeographic reconstructions of Barrier and Vrielynck (2008) and Agard et al. (2011), subduction trenches of Africa and Arabia below Eurasia were given constant bearings of 90 and $135^{\circ} \mathrm{E}$, respectively. For India, orthogonal subduction rate was obtained assuming a bearing of $110^{\circ} \mathrm{E}$, similar to the present orientation of the Indus-Yarlung Suture Zone between Indian and Asian rocks.

\section{Appendix B}

For oceanic crust and pelagic sediments, the decarbonation efficiency (defined as number of moles of $\mathrm{CO}_{2}$ emitted during a given time step of $0.5 \mathrm{Ma}), n \mathrm{CO}_{2}(t)$, is expressed as

$n \mathrm{CO}_{2}(t)=F_{\text {decarb }}$.

$\left(\frac{V_{\text {sed }}\left(t_{0}\right) \cdot \rho_{\text {sed }} \cdot\left(k_{1} \cdot W_{\mathrm{CaCO}_{3} \text {-sed }}+k_{2} \cdot W_{\mathrm{Corg}}\right)+k_{1} \cdot V_{\text {crust }}\left(t_{0}\right) \cdot \rho_{\text {crust }} \cdot W_{\mathrm{CaCO}_{3}-\text { crust }}}{M_{\mathrm{CO}_{2}}}\right)$,

where $V_{\text {sed }}\left(t_{0}\right)$ and $V_{\text {crust }}\left(t_{0}\right)$ designate the volume of subducting sediments and crust $\left(\mathrm{km}^{3}\right)$ for a given time step at $t_{0}=t-$ time-lag $(2 \mathrm{Ma}), \rho_{\text {sed }}$ and $\rho_{\text {crust }}$ are their den-

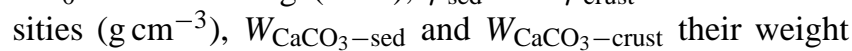
fraction of carbonate, $W_{\text {corg }}$ the weight fraction of organic carbon in sediments, $k_{1}$ and $k_{2}$ are conversion unit factors $\left(k_{1}=4.161 \times 10^{14} ; k_{2}=3.46 \times 10^{15}\right), M_{\mathrm{CO}_{2}}$ is the molecular weight of $\mathrm{CO}_{2}\left(44 \mathrm{~g} \mathrm{~mol}^{-1}\right)$ and $F_{\text {decarb }}$ is the decarbonation efficiency, defined as the mass percentage of carbon subducted as sedimentary carbonate, crustal carbonate and organic matter (carbon input), recycled as $\mathrm{CO}_{2}$. Subducted volumes $V\left(t_{0}\right)$ were calculated as follows:

$V\left(t_{0}\right)=H$.

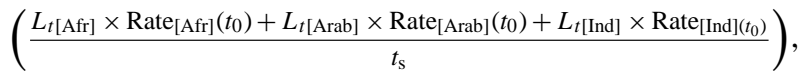

where, respectively for subducted sediment or crust volumes $V\left(t_{0}\right), H$ is the sediment or crust thicknesses $(\mathrm{km})$;
$\mathrm{Lt}_{[\mathrm{Afr}]}, \mathrm{Lt}_{[\mathrm{Arab}]}$ and $\mathrm{Lt}_{[\text {Ind] }}$ are the subduction trench lengths of Africa, Arabia and India $(\mathrm{km})$ and Rate $_{[\mathrm{Afr}]}$, Rate $_{[\mathrm{Arab}]}$ and Rate $_{[\text {Ind] }}$ the orthogonal subduction rates of Africa, Arabia and India beneath Eurasia at $\mathrm{t} 0\left(\mathrm{~km} \mathrm{Ma}^{-1}\right)$, and $t_{\mathrm{s}}$ is the time step (0.5 Ma in this study).

For continental crust and Indian margin sediments, the decarbonation efficiency (defined as number of moles of $\mathrm{CO}_{2}$ emitted by subducting Indian continental margin during a given time step of $0.5 \mathrm{Ma}), n \mathrm{CO}_{2}(t)_{[\text {Ind] }}$, was calculated using an expression close to Eq. (B3):

$$
\begin{aligned}
& n \mathrm{CO}_{2}(t)_{[\text {Ind }]}=F_{\text {decarb }} \\
& \quad\left(\frac{V_{\text {sed }}\left(t_{0}\right) \cdot \rho_{\text {sed }} \cdot\left(k_{1} \cdot W_{\mathrm{CaCO}_{3}-\mathrm{sed}}+k_{2} \cdot W_{\mathrm{Corg}}\right)}{M_{\mathrm{CO}_{2}}}\right)
\end{aligned}
$$

but where $V_{\text {sed }}\left(t_{0}\right), \rho_{\text {sed }}, W_{\mathrm{CaCO}_{3}-\text { sed }}, W_{\text {corg }}$ and $F_{\text {decarb }}$ have numerical values specific of margin instead of pelagic sediments. In this case, $t=t_{0}$ and $V_{\text {sed }}\left(t_{0}\right)$ is represented as

$$
V_{\text {sed }}\left(t_{0}\right)=V_{\text {sed }}(t)=H_{\text {sed }} \cdot\left(\frac{L_{t[\text { Ind }]} \times \operatorname{Rate}_{[\text {Ind }]}(t)}{t_{\mathrm{s}}}\right) .
$$


Acknowledgements. F. Behar and T. Parra are thanked for helpful discussions. The manuscript greatly benefited from reviews of D. V. Kent and J. Martinod. G. Hoareau and B. Bomou benefited from Post-doctoral grants from INSU- and INEE-CNRS.

Edited by: Y. Godderis

\section{References}

Agard, P., Omrani, J., Jolivet, L., Whitechurch, H., Vrielynck, B., Spakman, W., Monié, P., Meyer, B., and Wortel, R.: Zagros orogeny: a subduction-dominated process, Geol. Mag., 148, 692-725, 2011.

Alt, J. C. and Teagle, D. A. H.: The uptake of carbon during alteration of ocean crust: Geochim. Cosmochim. Ac., 63, 1527-1535, 1999.

Alvarez, W.: Protracted continental collisions argue for continental plates driven by basal traction, Earth Planet. Sc. Lett., 296, 434442, doi:10.1016/j.eps1.2010.05.030, 2010.

Barrier, E. and Vrielynck, B.: Paleotectonic Maps of the Middle East: Middle East Basins Evolution Programme, CCGMCGMW, Paris, 2008.

Beck, R. A., Burbank, D. W., Sercombe, W. J., Olson, T. L., and Khan, A. M.: Organic carbon exhumation and global warming during the early Himalayan collision, Geology, 23, 387-390, doi:10.1130/0091-7613(1995)023<0387:OCEAGW>2.3.CO;2, 1995.

Becker, J. A., Bickle, M. J., Galy, A., and Holland, T. J. B.: Himalayan metamorphic $\mathrm{CO}_{2}$ fluxes: quantitative constraints from hydrothermal springs, Earth Planet. Sc. Lett., 265, 616-629, 2008.

Beerling, D. J. and Royer, D. L.: Convergent cenozoic $\mathrm{CO}_{2}$ history, Nat. Geosci., 4, 418-420, 2011.

Bellon, H., Maury, R. C., Sutanto, Soeria-Atmadja, R., Cotten, J., and Polvé, M.: 65 m.y.-long magmatic activity in Sumatra (Indonesia), from Paleocene to present, B. Soc. Geol. Fr., 175, 6172, 2004.

Berner, R. A.: The Phanerozoic Carbon Cycle: $\mathrm{CO}_{2}$ and $\mathrm{O}_{2}$, Oxford University Press, New-York, 150 pp., 2004.

Berner, R. A.: Inclusion of weathering of volcanic rocks in the GEOCARBSULF model, Am. J. Sci., 306, 295-302, 2006.

Besse, J. and Courtillot, V.: Apparent and true polar wander and the geometry of the geomag- netic field over the last $200 \mathrm{Myr}$, J. Geophys. Res., 107, 2300, doi:10.1029/2000JB000050, 2002.

Boyden, J. A., Müller, R. D., Gurnis, M., Torsvik, T. H., Clark, J. A., Turner, M., Ivey-Law, H., Watson, R. J., and Cannon, J. S.: Next-generation plate-tectonic reconstructions using GPlates, in: Geoinformatics: Cyberinfrastructure for the Solid Earth, edited by: Keller, G. R. and Baru, C., Cambridge University Press, Cambridge, 95-114, 2011

Brookfield, M. E.: The Himalayan passive margin from Precambrian to Cretaceous times, Sediment. Geol., 84, 1-35, 1993.

Cramer, B. S., Toggweiler, J. R., Wright, J. D., Katz, M. E., and Miller, K. G.: Ocean overturning since the Late Cretaceous: inferences from a new benthic foraminiferal isotope compilation, Paleoceanography, 24, PA4216, doi:10.1029/2008PA001683, 2009.
Dercourt, J., Ricou, L. E., and Vrielynck, B.: Atlas Tethys Palaeoenvironmental Maps, Gauthier Villars, CGMW, Paris, 307 pp., 14 maps, 1993.

Dessert, C., Dupré, B., Gaillardet, J., François, L. M., and Allègre, C. J.: Basalt weathering laws and the impact of basalt weathering on the global carbon cycle, Chem. Geol., 202, 257-273, 2003.

Donnadieu, Y., Goddéris, Y., Ramstein, G., Nedelec, A., and Meert, J. G.: A "snowball Earth" climate triggered by continental breakup through changes in runoff, Nature, 418, 303-306, 2004.

Donnadieu, Y., Goddéris, Y., Pierrehumbert, R., Fluteau, F., and Dromart, G.: Pangea break up and Mesozoic climatic evolution simulated by the GEOCLIM model, Geochem. Geophy. Geosy., 7, Q11019, doi:10.1029/2006GC001278, 2006.

Dupont-Nivet, G., Lippert, P., van Hinsbergen, D. J. J., Meijers, M. J. M., and Kapp, P.: Paleolatitude and age of the Indo-Asia collision: paleomagnetic constraints, Geophys. J. Int., 182, 11891198, 2010.

Edmond, J. M. and Huh, Y.: Non-steady state carbonate recycling and implications for the evolution of atmospheric $p \mathrm{CO}_{2}$, Earth Planet. Sc. Lett., 216, 125-139, doi:10.1016/S0012821X(03)00510-7, 2003.

Eldholm, O. and Thomas, E.: Environmental impact of volcanic margin formation, Earth Planet. Sc. Lett., 117, 319-329, doi:10.1016/0012-821X(93)90087-P, 1993.

Engebretson, D. C., Kelley, K. P., Cashman, H. J., and Richards, M. A.: 180 million years of subduction, GSA Today, 2, 93-95, 1992.

England, P. C. and Katz, R. F.: Melting above the anhydrous solidus controls the location of volcanic arcs, Nature, 467, 700-703, doi:10.1038/nature09417, 2010.

Evans, M. J., Derry, L. A., and France-Lanord, C.: Degassing of metamorphic carbon dioxide from the Nepal Himalaya, Geochem. Geophy. Geosy., 9, Q04021, doi:10.1029/2007GC001796, 2008.

Eyuboglu, Y., Santosh, M., Dudas, F. O., Chung, S. L., and Akaryal1, E.: Migrating magmatism in a continental arc: geodynamics of the Eastern Mediterrenean revisited, J. Geodyn., 52, 2-15, 2011.

Friedrich, O., Norris, R. D., and Erbacher, J.: Evolution of middle to Late Cretaceous oceans - a 55 m.y. record of Earth's temperature and carbon cycle, Geology, 40, 107-110, doi:10.1130/G32701.1, 2012.

Froelich, F. and Misra, S.: Was the Late Paleocene-Early Eocene hot because Earth was flat? An ocean lithium isotope view of mountain building, continental weathering, carbon dioxide, and Earth's cenozoic climate, Oceanography, 27, 36-49, doi:10.5670/oceanog.2014.06, 2014

Gaina, C., van Hinsbergen, D. J. J., and Spakman, W.: Tectonic interactions between India and Arabia since the Jurassic reconstructed from marine geophysics, ophiolite geology, and seismic tomography, Tectonics, 34, 875-906, doi:10.1002/2014TC003780, 2015.

Garzanti, E. and $\mathrm{Hu}, \mathrm{X}$.: Latest Cretaceous Himalayan tectonics: obduction, collision or Deccan-related uplift?, Gondwana Res., 28, 165-178, 2014.

Gnos, E., Immenhauser, A., and Peters, T.: Late Cretaceous/Early Tertiary convergence between the Indian and Arabian plates recorded in ophiolitesand related sediments, Tectonophysics, 271, 1-20, 1997. 
Goddéris, Y. and Joachimski, M. M.: Global change in the Late Devonian: modelling the Frasnian-Famennian short-term carbon isotope excursions, Palaeogeogr. Palaeocl., 202, 309-329, 2004.

Goddéris, Y., Donnadieu, Y., Tombozafy, M., and Dessert, C.: Shield effect on continental weathering: implication for climatic evolution of the Earth at the geological time-scale, Geoderma, 145, 439-448, 2008.

Goddéris, Y., Donnadieu, Y., Le Hir, G., Lefebvre, V., and Nardin, E.: The role of palaeogeography in the Phanerozoic history of atmospheric $\mathrm{CO}_{2}$ and climate, Earth-Sci. Rev., 128, 122-138, 2014.

Gorman, P. J., Kerrick, D. M., and Connolly, J. A. D.: Modeling open system metamorphic decarbonation of subducting slabs, Geochem. Geophy. Geosy., 7, Q04007, doi:10.1029/2005GC001125, 2006.

Guillot, S., Maheo, G., de Sigoyer, J., Hattori, K. H., and Pecher, A.: Tethyan and Indian subduction viewed from the Himalayan high- to ultrahigh-pressure metamorphic rocks, Tectonophysics, 451, 225-241, 2008.

Hall, R.: Late Jurassic-Cenozoic reconstructions of the Indonesian region and the Indian Ocean, Tectonophysics, 570-571, 1-41, doi:10.1016/j.tecto.2012.04.021, 2012.

Hancock, H. J. L., Dickens, G. R., Thomas, E., and Blake, K. L.: Reappraisal of early Paleogene CCD curves: foraminiferal assemblages and stable carbon isotopes across the carbonate facies of Perth Abyssal Plain, Int. J. Earth Sci., 96, 925-946, doi:10.1007/s00531-006-0144-0, 2007.

Hébert, R., Bezard, R., Guilmette, C., Dostal, J., Wang., C. S., and Liu, Z. F.: The Yarlung Zangbo Ophiolites from Nanga Parbat to Namche Barwa syntaxes, Southern Tibet: a syntesis of petrology, geochemistry and ages with incidences on geodynamic reconstructions of the Neo-Tethys, in: Plate Tectonics of Asia: Geological and Geophysical Constraints, edited by: Zhao, X. X., Xiao, W. J., Wang., C. S., and Hébert, R., Gondwana Res., 22, 377-397, 2012.

Heine, C., Müller, R. D., Gaina, C., Clift, P., Kuhnt, W., Wang, P., and Hayes, D.: Reconstructing the lost eastern Tethys Ocean Basin: Convergence history of the SE Asian margin and marine gateways, Geophysical Monograph, 149, 37-54, doi:10.1029/149GM03, 2004.

Hilting, A. K., Kump, L. R., and Bralower, T. J.: Variations in the oceanic vertical carbon isotope gradient and their implications for the Paleocene-Eocene biological pump, Paleoceanography, 23, PA3222, doi:10.1029/2007PA001458, 2008.

Hilton, D. R., Fischer, T. P., and Marty, B.: Noble gases and volatile recycling at subduction zones, in: Noble Gases in Cosmochemistry and Geochemistry, edited by: Porcelli, D., Ballentine, C. J., and Wieler, R., Mineralogical Society of America, Washington, D.C., 319-370, 2002.

Hodell, D. A., Kamenov, G. D., Hathorne, E. C., Zachos, J. C., Röhl, U., and Westerhold, T.: Variations in the strontium isotope composition of seawater during the Paleocene and early Eocene from ODP Leg 208 (Walvis Ridge), Geochem. Geophy. Geosy., 8, Q09001, doi:10.1029/2007GC001607, 2007.

Hu, X., Wang, J., BouDagher-Fadel, M., Garzanti, E., and An, W.: New insights into the timing of the India-Asia collision from the Paleogene Quxia and Jialazi formations of the Xigaze forearc basin, South Tibet, Gondwana Res., doi:10.1016/j.gr.2015.02.007, in press, 2015.
Huang, W., van Hinsbergen, D. J. J., Maffione, M., Orme, D., Dupont-Nivet, G., Guilmette, C., Ding, L., Guo, Z., and Kapp, P.: Lower Cretaceous Xigaze ophiolites formed in the Gangdese forearc: evidence from paleomagnetism, sediment provenance, and stratigraphy, Earth Planet. Sc. Lett., 415, 142-153, 2015 a.

Huang, W., van Hinsbergen, D. J. J., Lippert, P. C., Guo, Z., DupontNivet, G., and Kapp, P.: Paleomagnetic tests of tectonic reconstructions of the India-Asia collision zone, Geophys. Res. Lett., 42, 2642-2649, doi:10.1002/2015GL063749, 2015b.

Jacob, R.: Low Frequency Variability in a Simulated Atmosphere Ocean System, PhD thesis, University of Wisconsin, Madison, USA, 1997.

Ji, W.-Q., Wu, F.-Y., Chung, S.-L., Li, J.-X, and Liu, C.-Z.: Zircon $\mathrm{U}-\mathrm{Pb}$ geochronology and $\mathrm{Hf}$ isotopic constraints on petrogenesis of the Gangdese batholith, southern Tibet, Chem. Geol., 262, 229-245, doi:10.1016/j.chemgeo.2009.01.020, 2009.

Johnston, K. B. F., Turchyn, A. V., and Edmonds, M.: Decarbonation efficiency in subduction zones: implications for warm Cretaceous climates, Earth Planet. Sc. Lett., 303, 143-152, doi:10.1016/j.epsl.2010.12.049, 2011.

Kazmin, V. G.: Collision and rifting in the Tethys Ocean: geodynamic implications, Tectonophysics, 123, 371-384, 1991.

Kent, D. V. and Muttoni, G.: Equatorial convergence of India and early Cenozoic climate trends, P. Natl. Acad. Sci. USA, 105, 16065-16070, doi:10.1073/pnas.0805382105, 2008.

Kent, D. V. and Muttoni, G.: Modulation of Late Cretaceous and Cenozoic climate by variable drawdown of atmospheric $p \mathrm{CO}_{2}$ from weathering of basaltic provinces on continents drifting through the equatorial humid belt, Clim. Past, 9, 525-546, doi:10.5194/cp-9-525-2013, 2013.

Kerrick, D. M. and Caldeira, K.: Paleoatmospheric consequences of $\mathrm{CO}_{2}$ released during early Cenozoic regional metamorphism in the Tethyan orogeny, Chem. Geol., 108, 201-230, doi:10.1016/0009-2541(93)90325-D, 1993.

Kerrick, D. M. and Caldeira, K.: Metamorphic $\mathrm{CO}_{2}$ degassing from orogenic belts, Chem. Geol., 145, 213-232, doi:10.1016/S00092541(97)00144-7, 1998.

Komar, N., Zeebe, R. E., and Dickens, G. R.: Understanding long-term carbon cycle trends: the late Paleocene through the early Eocene, Paleoceanography, 28, 650-662, doi:10.1002/palo.20060, 2013.

Kroeger, K. F. and Funnel, R. H.: Warm Eocene climate enhanced petroleum generation from Cretaceous source rocks: a potential climate feedback mechanism?, Geophys. Res. Lett., 39, L04701, doi:10.1029/2011GL050345, 2012.

Kroenke, L., Berger, W., Janecek, T., Backman, J., Bassinot, F., Corfield, R., Delaney, M., Hagen, R., Jansen, E., Krissek, L., Lange, C., Leckie, M., Lind, I., Mahoney, J., Marsters, J., Mayer, L., Mosher, D., Musgrave, R., Prentice, M., Resig, J., Schmidt, H., Stax, R., Storey, M., Takayama, T., Tarduno, J. A., Wilkins. R. H., and Wu, G.: Proceedings of the Ocean Drilling Program, Initial Reports, vol. 130, Ocean Drilling Program, College Station, Texas, doi:10.2973/odp.proc.ir.130.1991, 1991.

Kurtz, A., Kump, L. R., Arthur, M. A., Zachos, J. C., and Paytan, A.: Early Cenozoic decoupling of the global carbon and sulfur cycles, Paleoceanography, 18, 1090, doi:10.1029/2003PA000908, 2003.

Lee, C.-T. A., Shen, B., Slotnick, B. S., Liao, K., Dickens, G. R., Yokoyama, Y., Lenardic, A., Dasgupta, R., Jellinek, M., Lackey, 
J. S., Schneider, T., and Tice, M. M.: Continental arc-island arc fluctuations, growth of crustal carbonates, and long-term climate change, Geosphere, 9, 21-36, doi:10.1130/GES00822.1, 2013.

Leech, M. L., Singh, S., Jain, A. K., Klemperer, S. L., and Manickavasagam, R. M.: The onset of India-Asia continental collision: early, steep subduction required by the timing of UHP metamorphism in the western Himalaya, Earth Planet. Sc. Lett., 234, 8397, 2005.

Lefebvre, V., Donnadieu, Y., Goddéris, Y., Fluteau, F., and HubertTheìou, L.: Was the Antarctic glaciation delayed by a high degassing rate during the early Cenozoic?, Earth Planet. Sc. Lett., 371-372, 203-211, 2013.

Leon-Rodriguez, L. and Dickens, G. R.: Constraints on ocean acidification associated with rapid and massive carbon injections: the early Paleogene record at ocean drilling program site 1215 , equatorial Pacific Ocean, Palaeogeogr. Palaeocl., 298, 409-420, 2010.

Liu, G. and Einsele, G.: Sedimentary history of the Tethyan basin in the Tibetan Himalayas, Geol. Rundsch., 83, 32-61, 1994.

Marquer, D., Mercolli, I., and Peters, T.: Early Cretaceous intraoceanic rifting in the proto-Indian Ocean recorded in the Masirah Ophiolite, Sultanate of Oman, Tectonophysics, 292, 1-16, 1998.

Massonne, H.-J.: Phase relations and dehydration behaviour of calcareous sediments at very-low to low grade metamorphic conditions, Period. Mineralogia, 79, 21-43, 2010.

McCourt, W., M. Crow, E. Cobbing, and Amin, T.: Mesozoic and Cenozoic plutonic evolution of SE Asia: evidence from Sumatra, Indonesia, Special Publications, Geol. Soc. London, 106, 321335, 1996.

McQuarrie, N. and van Hinsbergen, D. J. J.: Retro-deforming the Arabia-Eurasia collision zone: age of collision versus magnitude of continental subduction, Geology, 41, 315-318, doi:10.1130/G33591.1, 2013.

Menzies, M. A., Klemperer, S. L., Ebinger, C. J., and Baker, J.: Characteristics of volcanic rifted margins, in: Volcanic Rifted Margins, 362, edited by: Menzies, M. A., Klemperer, S. L., Ebinger, C. J., and Baker, J., Geological Society of America Special Paper, 1-14, doi:10.1130/0-8137-2362-0.1, 2002.

Misra, S. and Froelich, P. N.: Lithium isotope history of Cenozoic seawater: changes in silicate weathering and reverse weathering, Science, 335, 818-823, doi:10.1126/science.1214697, 2012.

Mouthereau, F.: Timing of uplift in the Zagros belt/Iranian plateau and accommodation of late Cenozoic ArabiaEurasia convergence, Geol. Mag., 148, 726-738, doi:10.1017/s0016756811000306, 2011.

Müller, R. D., Sdrolias, M., Gaina, C., and Roest, W. R.: Age, spreading rates, and spreading asymmetry of the world's ocean crust, Geochem. Geophy. Geosy., 9, Q04006, doi:10.1029/2007GC001743, 2008.

Muttoni, G., Mattei, M., Balini, M., Zanchi, A., Gaetani, M., and Berra, F.: The drift history of Iran from the Ordovician to the Triassic, in: South Caspian to Central Iran Basins, edited by: Brunet, M.-F., Wilmsen, M., and Granath, J. W., Special Publictions, Geological Society of London, 7-29, 2009.

Najman, Y., Oliver, G., Parrish, R., Vezzoli, G., Appel, E., Boudagher-Fadel, M., Bown, P., Carter, A., Garzanti, E., Godin, L., Han, J., and Liebke, U.: Timing of India-Asia collision: geological, biostratigraphic, and palaeomagnetic constraints, J. Geophys. Res.-Sol. Ea., 115, B12416, doi:10.1029/2010JB007673, 2010 .
Nesbitt, B., Mendoza, C., and Kerrick, D., Surface fluid convection during cordilleran extension and the generation of metamorphic $\mathrm{CO}_{2}$ contributions to Cenozoic atmospheres, Geology, 23, 99101, 1995.

Okay, A. I. and Şahintürk, Ö.: Geology of the Eastern Pontides, in: Regional and Petroleum Geology of the Black Sea and Surrounding Region, edited by: Robinson, A. G., AAPG Memoir, 68, 291-311, 1997.

Orme, D. A., Carrapa, B., and Kapp, P. K.: Sedimentology, provenance and geochronology of the western Xigaze Forearc, Southern Tibet, Basin Res., 27, 387-411, doi:10.1111/bre.12080, 2014.

Pälike, H., Lyle, M. W., Nishi, H., Raffi, I., Ridgwell, A., Gamage, K., Klaus, A., Acton, G., Anderson, L., Backman, J., Baldauf, J., Beltran, C., Bohaty, S. M., Bown, P., Busch, W., Channell, J. E. T., Chun, C. O. J., Delaney, M., Dewangan, P., Dunkley Jones, T., Edgar, K. M., Evans, H., Fitch, P., Foster, G. L., Gussone, N., Hasegawa, H., Hathorne, E. C., Hayashi, H., Herrle, J. O., Holbourn, A., Hovan, S., Hyeong, K., Iijima, K., Ito, T., Kamikuri, S., Kimoto, K., Kuroda, J., Leon-Rodriguez, L., Malinverno, A., Moore, T. C., Murphy, B. H., Murphy, D.P., Nakamura, H., Ogane, K., Ohneiser, C., Richter, C., Robinson, R., Rohling, E. J., Romero, O., Sawada, K., Scher, H., Schneider, L., Sluijs, A., Takata, H., Tian, J., Tsujimoto, A., Wade, B. S., Westerhold, T., Wilkens, R., Williams, T., Wilson, P. A., Yamamoto, Y., Yamamoto, S., Yamazaki, T., and Zeebe, R. E.: A Cenozoic record of the equatorial Pacific carbonate compensation depth, Nature, 488, 609-614, 2012.

Park, J. and Royer, D. L.: Geologic constraints on the glacial amplification of Phanerozoic climate sensitivity, Am. J. Sci., 311, 1-26, doi:10.2475/01.2011.01, 2011.

Peacock, S. M.: Thermal structure and metamorphic evolution of subducting slabs, in: Inside the Subduction Factory, edited by: Eiler, J. M., Geophysical Monograph Ser. American Geophysical Union, Washington, D.C., 7-22, 2003.

Raymo, M. E. and Ruddiman, W. F.: Tectonic forcing of late Cenozoic climate, Nature, 359, 117-122, doi:10.1038/359117a0, 1992.

Reagan, M. K., McClelland, W. C., Girard, G., Goff, K. R., Peate, D. W., Ohara, Y., and Stern, R. J.: The geology of the southern Mariana fore-arc crust: implications for the scale of Eocene volcanism in the western Pacific, Earth Planet. Sc. Lett., 380, 41-51, doi:10.1016/j.eps1.2013.08.013, 2013.

Ricou, L. M.: Tethys reconstructed: plates, continental fragments and their boundaries since $260 \mathrm{Ma}$ from Central America to South-eastern Asia, Geodin. Acta, 7, 169-218, 1994.

Rohrmann, A., Kapp, P., Carrapa, B., Reiners, P. W., Guynn, J., Ding., L., and Heizler, M.: Thermochronologic evidence for plateau formation in central Tibet by $45 \mathrm{Ma}$, Geology, 40, 187190, doi:10.1130/G32530.1, 2012.

Rosenbaum, G., Lister, G. S., and Duboz, C.: Relative motions of Africa, Iberia and Europe during Alpine orogeny, Tectonophysics, 359, 117-129, doi:10.1016/S0040-1951(02)00442- 0, 2002.

Sanchez, V. I., Murphy, M. A., Robinson, A. C., Lapen, T. L., and Heizler, M. T.: Tectonic evolution of the India-Asia suture zone since Middle Eocene time, Lopukangri area, south-central Tibet, J. Asian Earth Sci., 62, 205-220, 2013. 
Sciunnach, D. and Garzanti, E.: Subsidence history of the Tethys Himalaya, Earth-Sci. Rev., 25, 179-198, 2012.

Searle, M. and Cox, J.: Tectonic setting, origin, and obduction of the Oman ophiolite, Geol. Soc. Am. Bull., 111, 104-122, 1999.

Sengör A. M. C., Altiner, D., Cin, A., Ustaömer T., and Hsü, K. J.: Origin and assembly of the Tethyside orogenic collapse at the expense of Gondwana Land, in: Gondwana and Tethys, edited by: Audley-Charles, M. G. and Hallam, A., Special Publications, Geological Society of London, 37, 119-181, 1988.

Shackleton, N. J. and Kennett, J. P.: Paleo-temperature history of the Cenozoic and the initiation of Antarctic glaciation: oxygen and carbon isotope analyses in DSDP Sites 277, 279 and 281, Initial Rep. Deep Sea, 29, 743-755, 1975.

Skelton, A.: Flux rates for water and carbon during greenschist facies metamorphism, Geology, 39, 43-46, doi:10.1130/G31328.1, 2011.

Slotnick, B. S., Lauretano, V., Backman, J., Dickens, G. R., Sluijs, A., and Lourens, L.: Early Paleogene variations in the calcite compensation depth: new constraints using old borehole sediments from across Ninetyeast Ridge, central Indian Ocean, Clim. Past, 11, 473-493, doi:10.5194/cp-11-473-2015, 2015.

Stampfli, G. M. and Borel, G. D.: A plate tectonic model for the Paleozoic and Mesozoic constrained by dynamic plate boundaries and restored synthetic oceanic isochrons, Earth Planet. Sc. Lett., 196, 17-33, doi:10.1016/S0012-821X(01)00588-X, 2002.

Sykes, T. J. S.: A correction for sediment load upon the ocean floor: uniform versus varying sediment density estimations implications for isostatic correction, Mar. Geol., 133, 35-49, doi:10.1016/0025-3227(96)00016-3, 1996.

Tera, F., Brown, L., Morris, J., Sacks, I. S., Klein, J., and Middleton, R.: Sediment incorporation in island-arc magmas: inferences from 10Be, Geochim. Cosmochim. Ac., 50, 535-550, 1986.

Turner, S. P.: On the time-scales of magmatism at islandarc volcanoes, Philos. T. Roy. Soc. A, 360, 2853-2871, doi:10.1098/rsta.2002.1060, 2002.

van Hinsbergen, D. J. J., Hafkenscheid, E., Spakman, W., Meulenkamp, J. E., and Wortel, M. J. R.: Nappe stacking resulting from subduction of oceanic and continental lithosphere below Greece, Geology, 33, 325-328, 2005.

van Hinsbergen, D. J. J., Steinberger, B, Doubrovine, P. V., and Gassmöller, R.: Acceleration and deceleration of IndiaAsia convergence since the Cretaceous: roles of mantle plumes and continental collision, J. Geophys. Res., 116, B06101, doi:10.1029/2010JB008051, 2011a. van Hinsbergen, D. J. J., Kapp, P., Dupont-Nivet, G., Lippert, P. C., DeCelles, P., and Torsvik, T.: Restoration of Cenozoic deformation in Asia and the size of Greater India, Tectonics, 30, TC5003, doi:10.1029/2010JB008051, 2011 b.

van Hinsbergen, D. J. J., Lippert, P. C., Dupont-Nivet, G., McQuarrie, N., Doubrovine, P. V., Spakman, W., and Torsvik, T. H.: Greater India Basin hypothesis and a two-stage Cenozoic collision between India and Asia, P. Natl. Acad. Sci. USA, 109, 7659-7664, doi:10.1073/pnas.1117262109, 2012.

Van Der Meer, D. G., Zeebe, R. E., van Hinsbergen, D. J. J., Sluijs, A., Spakman, W., and Torsvik, T. H.: Plate tectonic controls on atmospheric $\mathrm{CO}_{2}$ levels since the Triassic, P. Natl. Acad. Sci. USA, 111, 4380-4385, doi:10.1073/pnas.1315657111, 2014.

Vigier, N. and Goddéris, Y.: A new approach for modeling Cenozoic oceanic lithium isotope paleo-variations: the key role of climate, Clim. Past, 11, 635-645, doi:10.5194/cp-11-635- 2015, 2015

Walker, J. C. G., Hays, P. B., and Kasting, J. F.: A negative feedback mechanism for the long-term stabilization of Earth's surface temperature, J. Geophys. Res., 86, 9776-9782, 1981.

Watts, A. B. and Thorne, J. A.: Tectonics, global changes in sealevel and their relationship to stratigraphic sequences at the U.S. Atlantic continental margin, Mar. Petrol. Geol., 1, 319-339, 1984.

Whittaker, J. M., Müller, R. D., Sdrolias, M., and Heine, C.: SundaJava trench kinematics, slab window formation and overriding plate deformation since the Cretaceous, Earth Planet. Sc. Lett., 255, 445-457, doi:10.1016/j.epsl.2006.12.031, 2007.

Zachos, J. C., Pagani, M., Sloan, L., Thomas, E., and Billups, K.: Rhythms, and aberrations in global climate $65 \mathrm{Ma}$ to present, Science, 292, 686-693, doi:10.1126/science.1059412, 2001.

Zachos, J. C., Dickens, G. R., and Zeebe, R. E.: An early Cenozoic perspective on greenhouse warming and carboncycle dynamics: year of planet Earth, Nature, 451, 279-283, doi:10.1038/nature06588, 2008.

Zheng, Y.-F.: Metamorphic chemical geodynamics in continental subduction zones, Chem. Geol., 328, 5-48, 2012. 